\title{
The functional role of integrins during intra- and extravasation within the metastatic cascade
}

\author{
Greta Sökeland ${ }^{*}$ id and Udo Schumacher
}

\begin{abstract}
Formation of distant metastases is by far the most common cause of cancer-related deaths. The process of metastasis formation is complex, and within this complex process the formation of migratory cells, the so called epithelial mesenchymal transition (EMT), which enables cancer cells to break loose from the primary tumor mass and to enter the bloodstream, is of particular importance. To break loose from the primary cancer, cancer cells have to down-regulate the cell-to-cell adhesion molecules (CAMs) which keep them attached to neighboring cancer cells. In contrast to this downregulation of CAMS in the primary tumor, cancer cells up-regulate other types of CAMs, that enable them to attach to the endothelium in the organ of the future metastasis. During EMT, the expression of cell-to-cell and cell-to-matrix adhesion molecules and their down- and upregulation is therefore critical for metastasis formation. Tumor cells mimic leukocytes to enable transmigration of the endothelial barrier at the metastatic site. The attachment of leukocytes/cancer cells to the endothelium are mediated by several CAMs different from those at the site of the primary tumor. These CAMs and their ligands are organized in a sequential row, the leukocyte adhesion cascade. In this adhesion process, integrins and their ligands are centrally involved in the molecular interactions governing the transmigration. This review discusses the integrin expression patterns found on primary tumor cells and studies whether their expression correlates with tumor progression, metastatic capacity and prognosis. Simultaneously, further possible, but so far unclearly characterized, alternative adhesion molecules and/or ligands, will be considered and emerging therapeutic possibilities reviewed.
\end{abstract}

Keywords: Cancer, Epithelial mesenchymal transition, Selectin, Integrin, Integrin ligands, Leukocyte adhesion cascade, Metastasis, Extravasation, Prognosis, Integrin inhibitor

\section{Background}

\section{General steps of the metastatic cascade}

The capacity for metastatic dissemination as the ultimate attribute of malignancy is acquired during malignant progression. Vogelstein and Kinzler summarize this evolution towards malignancy as "Three Strikes to Cancer". Initially, a driver-gene mutation unleashing abnormal proliferation represents the first strike in the pathway to cancer. A second driver-gene mutation then initiates the expansion phase. This mutation enables the cell to thrive in its local environment and adapt to low-growth factor concentrations, oxygen, nutrients and functioning

\footnotetext{
* Correspondence: greta.soekeland@hotmail.de

Institute of Anatomy and Experimental Morphology, University Cancer Center, University Medical Center Hamburg Eppendorf, Martinistraße 52, 20246 Hamburg, Germany
}

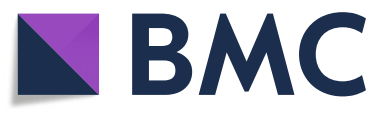

(C) The Author(s). 2019 Open Access This article is distributed under the terms of the Creative Commons Attribution 4.0 International License (http://creativecommons.org/licenses/by/4.0/), which permits unrestricted use, distribution, and reproduction in any medium, provided you give appropriate credit to the original author(s) and the source, provide a link to the Creative Commons license, and indicate if changes were made. The Creative Commons Public Domain Dedication waiver (http://creativecommons.org/publicdomain/zero/1.0/) applies to the data made available in this article, unless otherwise stated.

cell-to-cell contacts. After the first two strikes, cancer cells still satisfy criteria for benignity as they do not metastasize. The last strike driving the invasive phase brings on the malignant character of cancer, enabling it to invade surrounding tissues and disseminate through the body. However, despite considerable research efforts, a genetic signature for metastasis formation has not been identified [1]. The first step of metastasis formation consists in neoplastic cells loosening themselves from the primary tumor cell mass and breaking down the basement membrane of the tumor blood vessels, allowing stroma invasion and intravasation. The second step is for the cells to survive transport through the circulation, and as a third step, to arrest at the luminal side of the normal blood vessel endothelium in a distant organ (see Fig. 1). After transmigration of the endothelial 


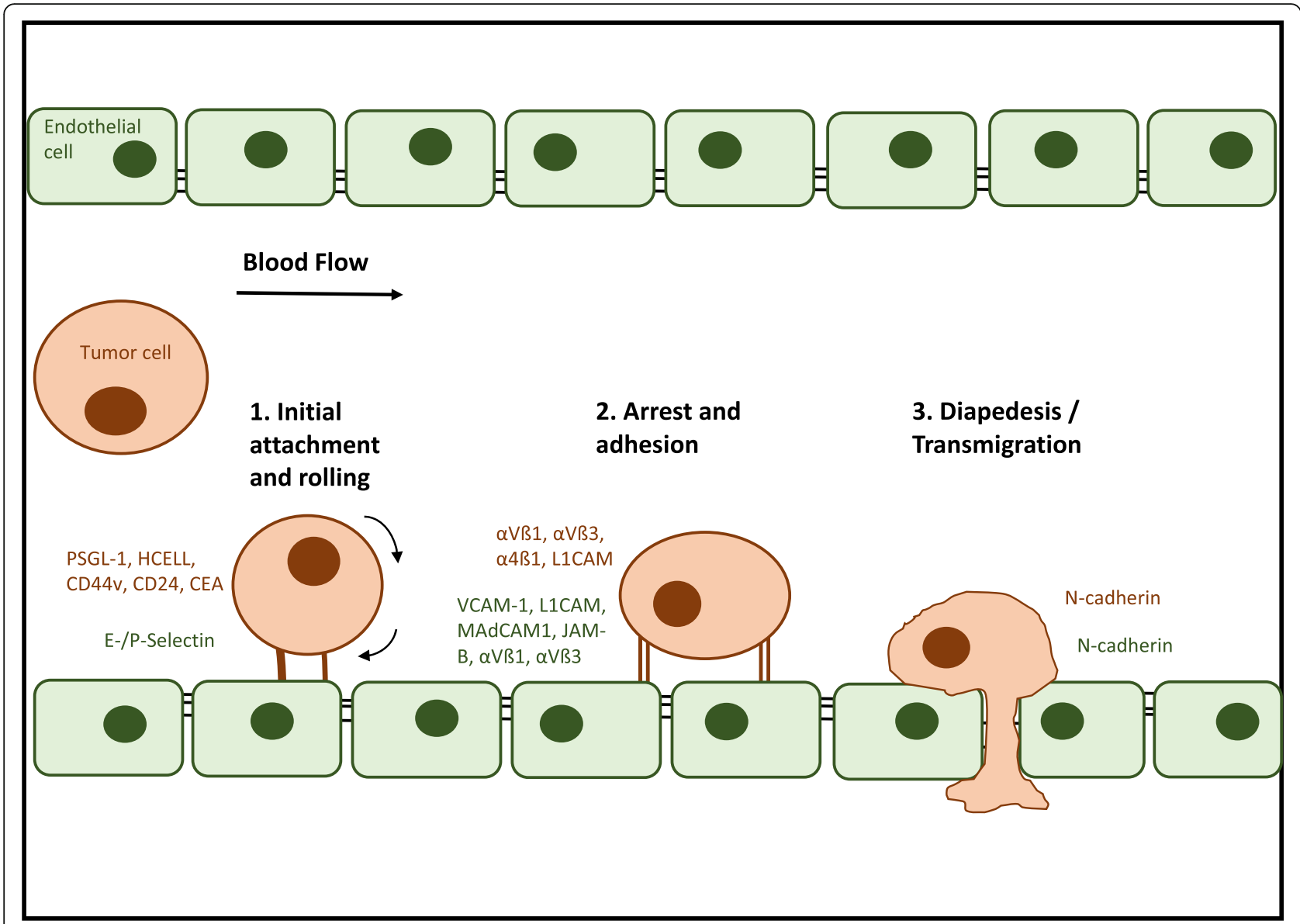

Fig. 1 The extravasation of tumor cells. To achieve improved clarity the figure is limited to the major adhesion molecules and their interactions. Tumor adhesion molecules are shown in brown, endothelial ligands are shown in green

barrier (fourth step), the cells have to adapt to the new microenvironment and have to commence proliferation (fifth step) [2]. The process by which the cancer cells gain migratory and invasive properties is called the epithelial-mesenchymal transition (EMT) [2]. Normal epithelial cells, from which cancer cells arise, are closely bound to their neighboring epithelial cells. This form of tissue organization is achieved through the sequential arrangement of adherens junctions, desmosomes and tight junctions [3]. The EMT program involves downregulation of cell-to-cell and cell-to-matrix adhesion molecules, dissolution of adherens and tight junctions and a loss of cell polarity, to overcome the natural barrier and become motile [2]. Additionally, mesenchymal cell adhesion molecules are upregulated and expressed on the cell surface, creating invasive cells with both a mesenchymal and a stem cell-like phenotype, enabling dissemination [3]. At the metastatic site this transition is reversed by the process of mesenchymal-epithelial transition (MET). This conversion to a more epithelial cell phenotype embodies an important factor in the formation of macrometastasis and metastatic colonization [3]. These findings suggest that transformation of the cancer cell adhesion molecule pattern may play the key role in metastatic spread.

This review focuses on the role of integrins and other adhesion molecules for tumor cell extravasation in metastatic dissemination (see Fig. 1). It examines whether mesenchymal adhesion molecules and/or the expression of their ligands on cancer cells correlates with tumor progression, metastatic capacity and prognosis. Additionally, their value as prognostic markers and their potential as oncologic treatment targets will be discussed.

\section{Extravasation of leukocytes and tumor cells}

Extravasation constitutes a multistep phenomenon that can be divided into different phases. The extravasation process is initialized by rolling, relatively low-affinity binding, of leukocytes and/or tumor cells mediated by the selectin family of adhesion molecules (see Fig. 1). Rolling is followed by tight adhesion through integrins and other adhesion molecules. After adhesion, leukocytes and tumor cells transmigrate through the vascular endothelium by a procedure named diapedesis. 
Leukocytes are able to transmigrate following a paracellular or transcellular route driven by adhesion molecule interactions [4]. In contrast to leukocytes, presumably cancer cells do not leave the endothelium intact after diapedesis. This seems reasonable if one keeps in mind the size of tumor cells in comparison to leukocytes [4]. One of the few mechanisms known for tumor cell diapedesis lies in N-cadherin interactions [5] (Fig. 1). This insufficiency in knowledge of means for diapedesis of tumor cells should be subject for further examination. The complete process of extravasation is also known as the leukocyte adhesion cascade as its steps have to be followed in a sequential order. However, some redundancy within the molecules involved in this cascade may be possible. In leukocytes, this cascade is a physiological process they use to migrate to inflammatory sites. In contrast, tumor cells take advantage of this mechanism in hematogenous metastasis to disperse through the blood circulation in the entire body [4] (see Fig. 1).

\section{Selectin mediated rolling}

The cells move to the margin of the blood stream (margination) where rolling is initiated by selectins, lectin cell adhesion molecules, expressed on the surface of leukocytes and endothelial cells [4] (see Fig. 1). The selectins are one of the smallest human gene families, consisting of three members only, namely $\mathrm{E}$ (ndothelial)-, $\mathrm{P}$ (latelet)and L(ymphocyte) selectin. E- and P-selectins expressed by endothelial cells are of particular importance for the extravasation of leukocytes at inflammation sites and for the purpose of metastasis formation [6]. E-selectin (CD62E) is expressed in the first hours of immune-inflammatory reactions, mediating the interaction with leukocytes (e. g. neutrophils and lymphocytes). E-selectin is synthesized de novo by cytokine-activated (e. g. IL-1, TNF $\alpha$ or interferon- $\gamma$ ) endothelial cells [7]. In addition, E-selectins are constitutively expressed on skin and bone microvascular endothelium and in the vasculature of the bronchial mucosa [6]. They represent binding partners for PSGL-1 (P-selectin glycoprotein ligand-1) and CLA (cutaneous lymphocyte antigen, decorated PGSL-1) found on monocytes, neutrophils and lymphocytes [6]. Additionally, HCELL (hematopoietic cell E-/L-selectin ligand) [8], found on stem cells, and CD34 act as a E-selectin ligand. $\mathrm{P}$-selectin (CD62P) is pre-synthesized and stored in Weibel-Palade bodies of the endothelium and $\alpha$-granules of platelets [6]. Pro-inflammatory mediators such as cytokines and histamine lead to an instant expression at the luminal surface of endothelial cells [7, 9].

Tumor cells exploit these mechanisms used by leukocytes to roll, arrest and adhere to the vascular endothelium $[6,10,11]$ (see Fig. 2). The extravasation of colon cancer cells is regulated by the activation of E-selectin on the endothelial layer. By means of a p38- and
ERK-dependent signaling pathway the integrity of the endothelium is modified, contributing to tumor cell extravasation [12]. LS174T colon carcinoma cell lines make use of the CD44 glycoform also known as hematopoietic cell E-/L-selectin ligand (HCELL) to interact with Eand L-selectin [13]. Furthermore, other variant isoforms of CD44 (CD44v) on LS174T colon cancer cells retain P-, L-, E-selectin binding activity [14]. Similar E-selectin interactions have been seen in other colon carcinoma cell lines $[15,16]$. Moreover the carcinoembryonic antigen (CEA) has been identified as a potential binding partner for E- and L-selectin [17]. Prostate cancer cells express glycoprotein and glycosphingolipid structures containing sialyl Lewis $\mathrm{X}$ epitopes to adhere to E-selectin on bone marrow endothelial cells, promoting metastatic dissemination into the bone [18]. PSGL-1 containing sialyl Lewis X epitopes, have been identified as one ligand for E-selectin in prostate cancer cells [19]. Additionally, CD24 expressed on breast cancer cells acts as an alternative interaction partner for E-selectin [20]. In conclusion, E-selectin acts as a homing receptor in the hematogenous dissemination of breast cancer [21], lung adenocarcinoma [22], prostate cancer [18], colon cancer [13] and pancreatic carcinoma cells [23]. P-selectins expressed by platelets may also adhere to selectin ligands on tumor cells or mucin fragments released by neoplastic cells, forming a bridge between the carcinoma cells, the platelets and the inflamed vasculature (see Fig. 2) [6].

Less importance in metastatic spread has been attributed to L-selectins. In contrast to E- and P-selectins, L-selectins (CD62L) are not expressed by endothelial cells. Instead, they are found on the surface of lymphocytes and other types of leukocytes, such as neutrophils and monocytes [24]. They mediate rolling on high endothelial venules, by binding to constitutively expressed ligands, summarized as peripheral lymph node addressins [4]. Similar to P-selectins, L-selectins might allow the formation of a bridge between tumor cells and the endothelium through a leukocyte (instead of a platelet) as an intermediate [6] (see Fig. 2). Data collected from Läubli et al. suggests that L-selectin-interactions of leukocytes at the sites of embolization may enhance tumor cell extravasation [25]. Lastly, N-cadherin has been observed to play a minor role in the regulation of rolling and adhesion of for eg. MDA-MB-468 human breast carcinoma cells by the means of a $\mathrm{N}$-cadherin $/ \mathrm{N}$-cadherin interaction [4, 26] (see Fig. 2).

\section{Integrin mediated adhesion}

During this selectin-mediated rolling, integrins are activated, bind to their endothelial ligands and permit the tight adhesion of leukocytes [4]. Integrins are a large family of homologous transmembrane cell adhesion 


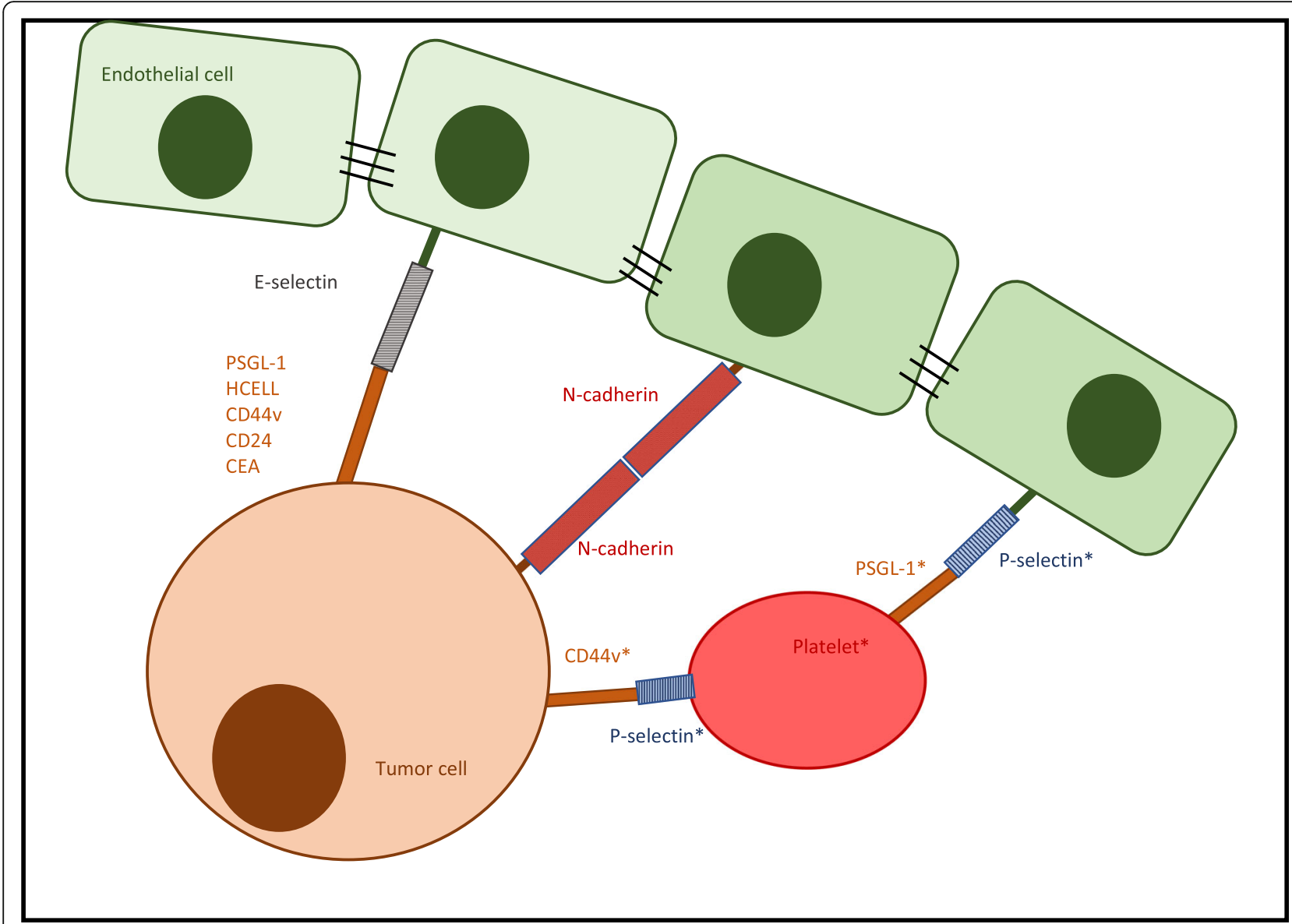

Fig. 2 Rolling of tumor cells. Representation of tumor cell rolling mediated by the interaction with selectin adhesion molecules. $\left({ }^{*}\right)$ Example of a possible interaction between tumor cell and the endothelium using an intermediate to link both interaction partners, forming a bridge [6, 156]

proteins that tie the matrix to the cytoskeleton or serve as cell-to-cell adhesion molecules [27] (see Fig. 3). The connection between integrins and the cytoskeleton is mediated by the integrin adhesome network, also known as integrin adhesion complex (IAC) [28]. Integrins consist of two non-covalently associated transmembrane glycoprotein subunits described as $\alpha$ and $ß$. The $\alpha$ subunit determines integrin-ligand specificity, whilst the $\beta$ subunit is connected to the cytoskeleton and affects different signaling pathways [29]. In vertebrates, $18 \alpha$ and 8 $\beta$ subunits have been described that can assemble into 24 heterodimers [30, 31]. Nine of the $18 \alpha$ chains contain an $\alpha \mathrm{I}$ domain consisting of an approximately 190200 amino acid residue sequence near the $\mathrm{N}$ terminus of the integrin $\alpha$ subunit $[32,33]$. This domain is found in the $\beta 2$ integrin subgroup, $\alpha E ß 7$ and in the collagen-binding $\beta 1$ integrins ( $\alpha 1, \alpha 2, \alpha 10$ and $\alpha 11)$ [29]. Ligand-binding depends on a coordinating $\mathrm{Mg}^{2+}$ ion in the metal-ion-dependent adhesion site (MIDAS) motif in the $\alpha \mathrm{I}$ domain bridging ligand binding [32]. The $\beta$ subunit contains a $ß I$ domain with an $\mathrm{Mg}^{2+}$ coordinating MIDAS and a region adjacent to it (ADMIDAS), binding an inhibitory $\mathrm{Ca}^{2+}$ ion [31]. The active form of the integrin is achieved by $\mathrm{Mn}^{2+}$ ions binding to the ADMIDAS site and thereby inducing a conformational change [31]. The $\beta I$ domain plays a role in ligand binding in non- $\alpha \mathrm{I}$ containing integrins [29] (see Fig. 3).

Ligand recognition seems to be mediated by conformational changes dictating active and inactive states of integrins [34]. The general mechanisms of ligand recognition are thought to be alterations in the tertiary conformation of the $\alpha \mathrm{I}$ domains deciding upon the activation state of $\$ 2$ integrins; quaternary structural changes likely also play a role [34]. Recognition is further brought about by signaling generated by the assembly of complexes, the adhesome network, on the cytoplasmatic side of the membrane [35]. Activation of leukocytes can arise from "inside-out signaling" triggered by agonists binding to different receptors, thus allowing ligand recognition by $ß 2$ integrins, causing changes in affinity and avidity. In addition, the involvement of integrins conveys "outside-in signaling", giving rise to intracellular transduction cascades that mediate functional responses and the integration with other signals 


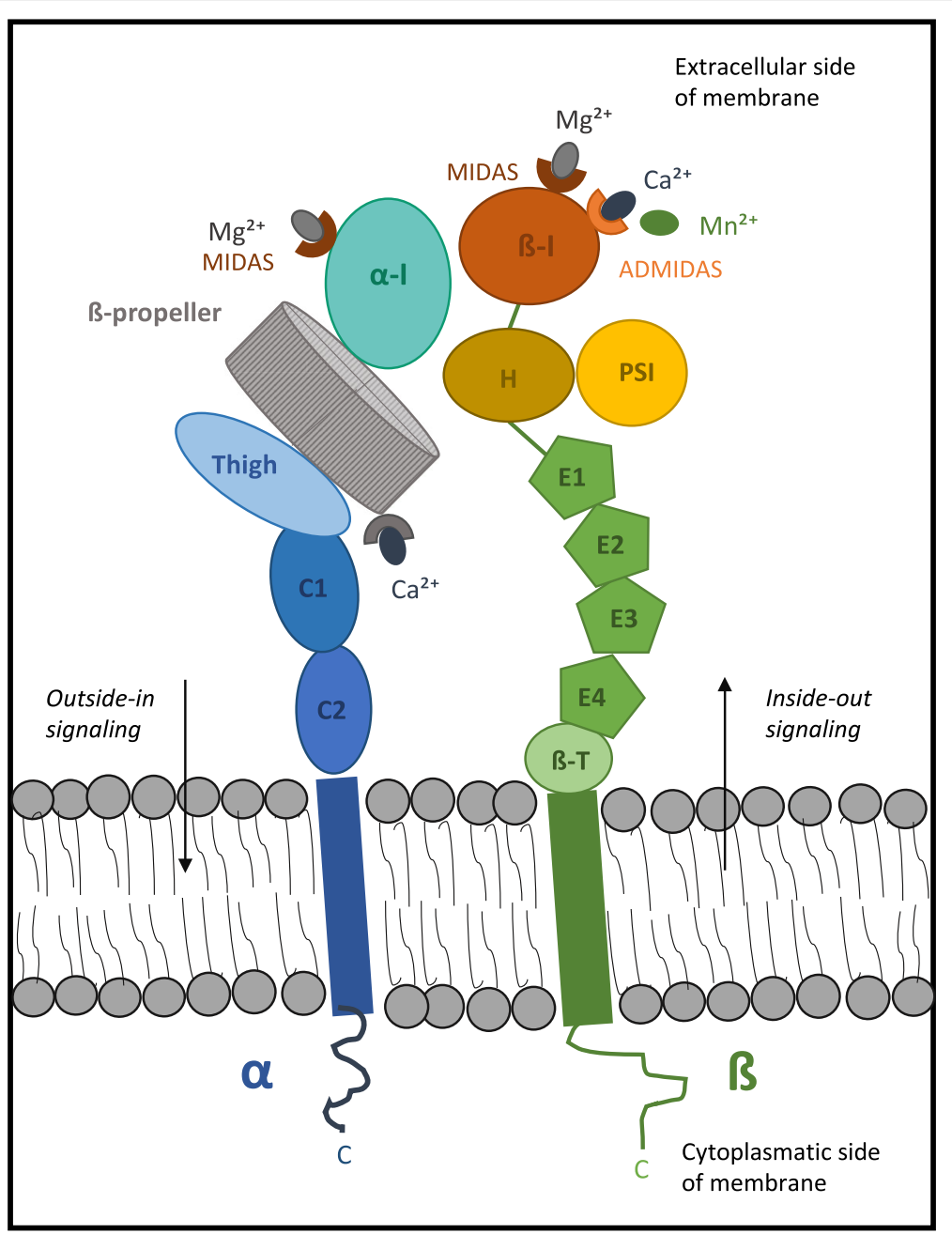

Fig. 3 Representation of an al-domain-containing integrin heterodimer and the distribution of its domains. All integrins contain a BI domain in the $\beta$ subunit, whilst nine out of the 18 integrin a chains contain an al-domain of around 200 amino acids, inserted between blades two and three of the $B$-propeller $[35,157]$. The a subunit is formed by a calf-2 (C2), calf-1 (C1) and a thigh domain supporting the seven-bladed Bpropeller [31]. The al-domain is coordinated by a $\mathrm{Mg}^{2+}$ ion in the metal-ion-dependent adhesion site (MIDAS) and represents the ligand-binding site. The $B$ subunit contains a MIDAS and ADMIDAS site mediating conformational changes resulting in an active form of the integrin. The $B$ subunit contains a ßI-domain, a hybrid domain (H), a plexin-semaphorin-integrin (PSI), four cysteine-rich epidermal growth factor repeats (E1-4) and a B-tail/transmembrane (B-T) domain [35]. As bi-directional signaling receptors, integrins convey inside-out and outside-in signaling [31]

[34] (see Fig. 3). Due to the fact that integrins lack enzymatic activity, signaling is instead induced by the arrangement of signaling complexes on the cytoplasmatic side of the plasma membrane [35]. The assembly is reached about by receptor clustering and by activating conformational changes that generate or expose binding sites [35].

A key characteristic of most integrins is their capability to bind to a wide repertoire of ligands. Undeniably, the expanse of the integrin family is outrun by their number of ligands [27]. Determinants of the integrin-ligand interaction are the affinity and the conformational state of the integrin and the availability and conformational state of the ligand. These characteristics dictate the choice of any given integrin to interact with one of their multiple ligands. To further add to the complexity of the interactions, integrin ligands, that is to say other adhesion molecules and extracellular matrix proteins, bind to multiple integrins and have no unique specific binding partner [27, 36]. Nevertheless, it is possible to divide integrin-ligand combinations according to their underlying structure, driving molecular interaction into four distinct classes, keeping in mind that other additional interactions exist [37]. This division may be a starting point at which to systematize the complex network of integrin interactions and to understand the integrin patterns tumor cells may use to imitate leukocyte extravasation. Humphries et al. differentiated between RGD-binding integrins: $\alpha \mathrm{V}, \beta 1(\alpha 5, \alpha 8)$ and $\alpha I \mathrm{IIb} \beta 3$, recognizing ligands with an RGD active site. The RGD 
motif (tripeptide Arg-Gly-Asp) interacts at an interface between $\alpha$ and $\beta$ subunits. The $\mathrm{R}$ residue binding with a $ß$-propeller module and the $\mathrm{D}$ coordinating a cation bound in the $B I$ domain [37]. In contrast, LDV- binding integrins $(\alpha 4 ß 1, \alpha 4 ß 7, \alpha 9 ß 1, ß 2$ subfamily, $\alpha E ß 7)$ interact with LDV motifs (Leu-Asp-Val) on their ligands and can contain $\alpha$ I domains (see Fig. 4). Additional classes are represented by the A-domain ( $\alpha$ I domain) $(\alpha 1, \alpha 2$, $\alpha 10, \alpha 11) \beta 1$ integrins binding to laminin and collagen and the Non $\alpha \mathrm{A}$-domain-containing laminin-binding integrins ( $\alpha 3 ß 1, \alpha 6 ß 1, \alpha 7 ß 1, \alpha 6 ß 4)$ [37].

The $\beta 2$ and $B 7$ heterodimers are restricted to cells of the leukocyte lineage [29] (see Fig. 4). Each class of leukocytes expresses a specific pattern of integrins. A common characteristic is that every leukocyte subtype expresses at least a single member of the $\$ 2$ integrin family [34]. Integrin $\alpha 4 ß 1$ is expressed on monocytes, on neutrophils in the case of sepsicemia [38] and on T cells. In $\mathrm{T}$ cells the integrin associated protein $\mathrm{CD} 47$ regulates adhesion of the 32 -integrins VLA-4 ( $\alpha 4 \beta 1)$, as well as LFA-1. Integrin VLA-4 is additionally expressed on immune globulin G-producing plasma cells [39]. Instead of expressing VLA-4, B cells synthesizing IgA antibodies make use of integrin $\alpha 4 \beta 7$ to migrate to mucosal tissues $[39,40]$. Furthermore, $\alpha 4 \beta 7$ integrin is expressed on homing $\mathrm{T}$ cells playing a role in the ability to migrate to skin and gut [40]. Memory $\mathrm{T}$ cells express $\alpha 4 ß 1$ and LFA-1 for trafficking [41]. All integrins expressed on leukocytes, including $\alpha 4 \beta 1, \alpha 9 ß 1, \alpha \mathrm{L} \beta 2, \alpha M ß 2, \alpha X \beta 2$, $\alpha D ß 2, \alpha E ß 7$ and $\alpha 4 ß 7$ integrins, represent LDV-binding integrins [37] (see Fig. 4).

Although leukocytes express specific integrins for the interaction with ligands during extravasation, these leukocyte-integrins could be substituted on tumor cells by other integrins or adhesion molecules with the ability

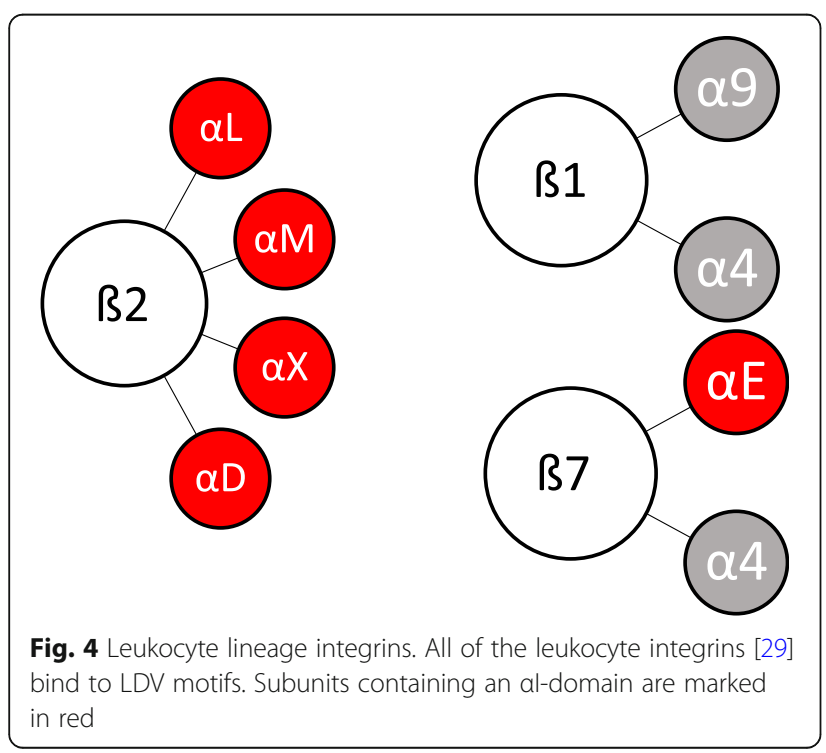

to bind to the same ligands on the vascular endothelium. This is due to the fact that a wide range of ligands may bind to a single integrin and vice versa. Thereupon, tumor cells wouldn't mimic leukocytes by expressing identical integrin patterns but by expressing integrins and adhesion molecules with receptors for the same ligands on the vascular endothelium. It appears that the binding pattern of leukocytes and tumor cells could be identical, despite the fact that their integrins may differ. Furthermore, tumor cells possess alternative ways of extravasation, such as the use of leukocytes as linker cells [4].

\section{Integrins expressed on leukocytes and tumor cells and their ligands}

Integrin aLß2 (LFA-1) and adhesion molecule ICAM-1

The adhesion of leukocytes is achieved by different types of integrins. Integrin $\alpha \mathrm{L} ß 2$ (lymphocyte function associated antigen LFA-1) acts as a ligand for ICAM-1 (intercellular adhesion molecule 1, CD54) [42] ICAM-2 (CD102) [43] and the junctional adhesion molecule A (JAM-A, member of immunoglobulin superfamily) [44]. Furthermore, the integrin $\alpha \mathrm{M} \beta 2$ (Mac-1) can bind to ICAM-1/- 2 and JAM-C on the endothelium [45, 46]. ß2-Integrin LFA-1 is expressed on neutrophils and lymphocytes, whereas Mac-1 is mainly found on neutrophils [39]. Tumor cells do not express such integrins; nevertheless, they possess the ability to express ICAM- 1 and use leukocytes as linker cells to adhere to the vascular endothelium [4](Fig. 4). In this way, they adhere to the vascular endothelium by means of an ICAM-1/LFA-1 interaction with the leukocyte, which for its part binds to ICAM-1 on the endothelium through LFA-1.

The genes on chromosome 19p13.2 encoding intercellular adhesion molecules (ICAM) have been determined as a cancer susceptibility locus $[47,48]$. In vitro targeting of ICAM1 reduced breast cancer cell invasion and metastasis [48]. Furthermore, ICAM1 expression correlated with the metastatic capacity of five human breast cancer cell lines, suggesting its key role in invasion and dissemination [48]. It has been shown that MDA-MB-468 human breast carcinoma cells use leukocytes as linker cells to adhere to lung endothelial cells [26]. Being ß2-integrin negative, they express ICAM-1, which interacts with $\alpha M ß 2$ or $\alpha \mathrm{L} ß 2$ on neutrophil granulocytes. The neutrophil granulocytes then, via $\alpha \mathrm{M} \beta 2$ or $\alpha \mathrm{L} \beta 2$, bind to the L1-CAM-positive endothelial cells [26] (Fig. 5). The use of leukocytes as linker cells for adhesion and transmigration has further been observed in melanoma cell metastatic dissemination [49]. Melanoma cells bind to ß2-integrins on polymorphonuclear neutrophils (PMN) via ICAM-1, whereas PMN themselves bind to ICAM-1 present on the endothelium [49]. ICAM-1 is further expressed in oral squamous cell carcinoma (SCC). 


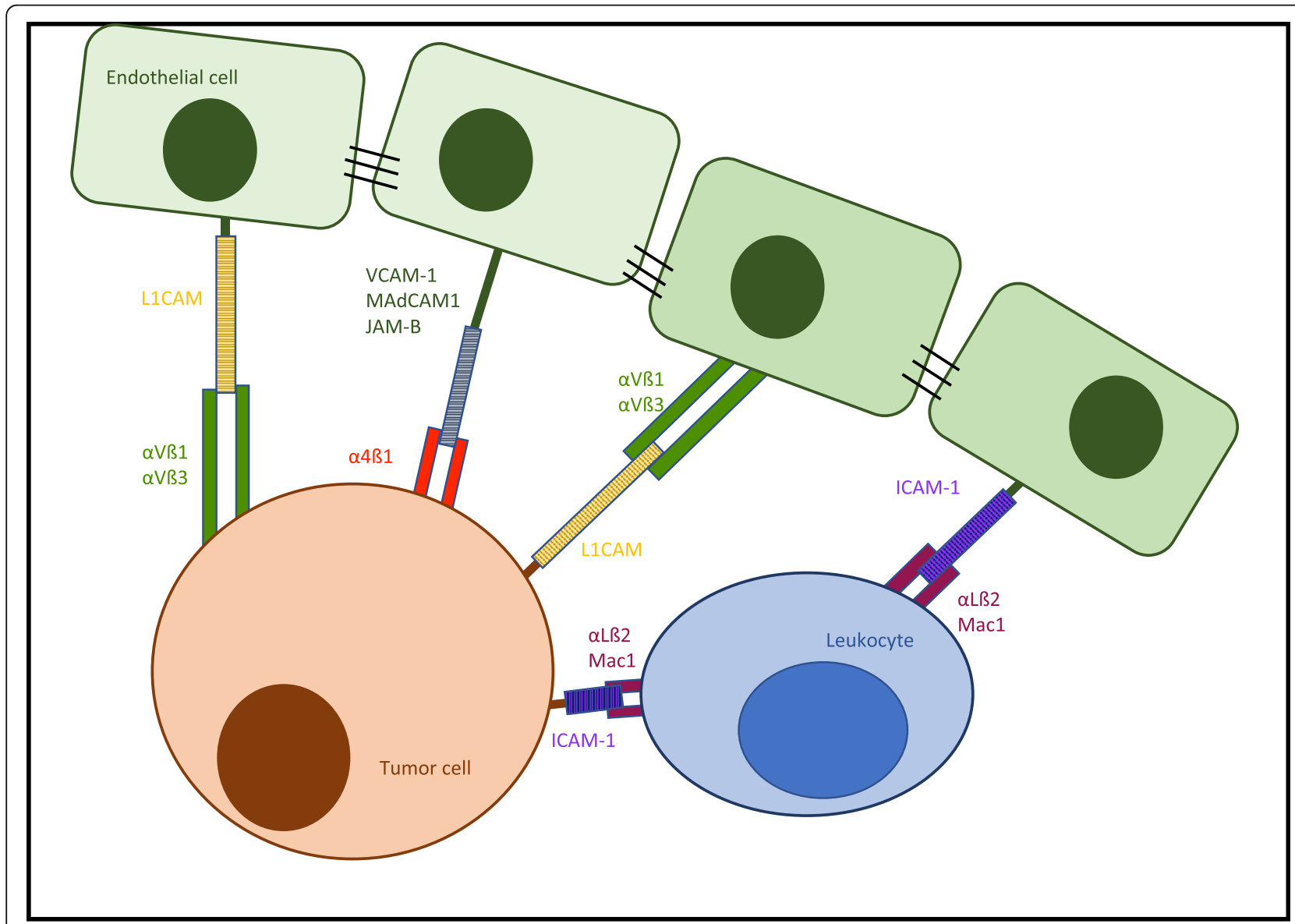

Fig. 5 Tumor cell adhesion molecules. Representation of cell adhesion mediated by integrins and other cell adhesion molecules binding to their corresponding endothelial ligands. Depiction of the specific integrins that are found overexpressed on tumor cells allowing extravasation and formation of distant metastases

Analysis has revealed that it is predominantly found at the invasive front of oral squamous carcinoma and its expression correlates with the level of invasion and lymph node dissemination [50]. Its expression is also associated with increased angiogenic and lymphangiogenic activity [50]. ICAM-1 increases the metastatic capacity of esophageal squamous cell carcinoma cells (ESCC) and stimulates tumorigenesis in a mouse model [51]. It further enhances sphere formation and therefore raises resistance to radio- and chemotherapy. These cancer characteristics have partly been attributed to a p53-dependent pathway [51].

Additionally, ICAM-1 upregulation is found in aggressive papillary thyroid carcinoma cells. Expression levels correlate with tumor malignancy, angiolymphatic invasion and metastasis [52]. Poorly differentiated thyroid carcinomas show higher ICAM-1 expression levels than well-differentiated carcinomas, supporting the thesis that ICAM-1 upregulation induces a more aggressive tumor phenotype [52]. Similar findings in investigations of
ICAM-1 expression in salivary adenoid cystic carcinoma accentuate the role in hematogenous metastasis. Salivary adenoid cystic carcinoma cells use leukocytes as a bridge to attach to the endothelium by means of ICAM-1. Expression levels correlate with lymph node invasion and local recurrence [53]. ICAM-1 expression was expressed in half of a gastric patient collective (49.0\% of 108 gastric cancer patients), and its expression levels were associated with a more advanced stage of gastric cancer and lymph node metastasis [54]. Higher ICAM-1expression levels were detected in most (90.9\%) of the gastric cancer patients with liver metastasis [54]. Patients with non-small-cell lung cancer have been shown to have higher serum levels of sICAM-1 (soluble ICAM-1) and increased ICAM-1 expression. Rising slCAM-1 levels predicted a short-term fatal outcome, whilst total levels had no prognostic value [55].

ICAM-1 is important in the metastatic spread of osteosarcoma cancer cells. It has been shown that TGF $\alpha$ in osteosarcoma increases ICAM-1 expression levels, 
transforming cancer cells into a more motile, invasive and adhesive phenotype [56]. Likewise, in prostate cancer, bradykinin, which has been shown to promote tumor expansion and dissemination, enhances migration and spread by augmenting ICAM-1 expression [57]. A study by Belal Al-Husein et al. revealed that micrometastasis in prostate cancer could be inhibited by blocking integrin $\alpha \mathrm{V} ß 3$ and ICAM-1, thus implying its function in overcoming the endothelial barrier and allowing hematogenous metastasis [58]. In addition, $\alpha \mathrm{V} ß 3$ integrin is essential for prostate cancer cell migration and adherence to bone matrix [59].

ICAM-1 expression has been observed in a heterogenous group of cancer entities described above, such as breast cancer [48], esophageal squamous cell carcinoma (ESCC) [51] and non-small-cell lung cancer [55] (see Table 2). In all these entities high ICAM-1 expression levels were associated with a more invasive, aggressive and motile phenotype allowing metastatic dissemination. Findings in ESCC even suggest that ICAM-1 expression may contribute to resistance against radio- and chemotherapy [51]. These findings and first in vitro studies on ICAM-1 expression or ICAM-1 regulatory pathway inhibition bring to mind its potential for targeted therapy and future prevention of metastasis [48, 58]. It still needs to be further determined whether the height of ICAM-1 levels could have prognostic value and if the levels have a clinical relevance and could be used for risk stratification to foresee adverse outcomes in oncologic patients.

The fact that integrins $\alpha \mathrm{D} \beta 2, \alpha \mathrm{M} \beta 2$ and $\alpha \mathrm{X} \beta 2$ also show interaction with ICAM-1 makes them possible alternative binding partners that tumor cells could make use of to accomplish adhesion [37] (Table 2). It remains to be determined whether $\alpha \mathrm{D} \beta 2$ and $\alpha \mathrm{M} \beta 2$ are expressed on cancer cells. First studies on $\alpha \mathrm{X} \beta 2$ (CD11c) expression in tumors do not suggest an involvement in metastasis and even seem to indicate a favorable prognosis in gastric cancer [60]. Nevertheless, this is due to the fact that $\alpha \mathrm{X} \beta 2$ is expressed on tumor-infiltrating dendritic cells that mediate an anti-tumor immune response [60]. In this analysis, no expression of $\alpha \mathrm{X} ß 2$ on tumor cells was shown, and therefore, the assumption that tumor cells make use of $\alpha \mathrm{X} \beta 2$ as an alternative ligand for ICAM-1 still needs to be further investigated.

\section{Integrin a4ß1 (VLA-4) and adhesion molecule VCAM-1}

In the case of septicemia, neutrophil granulocytes express $\alpha 4 ß 1$ (very late antigen 4, VLA-4) on their surface [38], acting as a ligand for VCAM-1 (vascular cellular adhesion molecule 1, CD106), which is upregulated in response to inflammatory mediators. Similarly, the major integrin mediating firm adhesion in monocytes is VLA-4 (see Table 1). It is also expressed by lymphocytes granting adhesive functions [39]. Apart from attaching to VCAM-1, the junctional adhesion molecule B (JAM-B) represents an alternative binding partner [45]. In tumor cells, $\alpha 4 ß 1$ and $\alpha 4 ß 7$ integrins serve as alternative ligands for VCAM- 1 and have been associated with the metastatic capacity of cancer [4, 61, 62] (see Fig. 5) (see Table 2). Additionally, VCAM-1, itself expressed on cancer cells, has been determined as a driver of metastatic dissemination due its competence to bind to $\alpha 4 \beta 1$ found on the endothelium in lymph nodes [63].

High levels of integrin $\alpha 4 ß 1$ have been identified on A375M melanoma cells, allowing them to adhere to VCAM-1 on the vascular endothelium. In a mouse model, pulmonary metastasis formation could be stimulated by enhancing $\alpha 4 ß 1$ expression [61]. Likewise, lung colonization in B16-BL6 melanoma was increased by TNF $\alpha$ administration mediating higher levels of $\alpha 4 \beta 1$ expression [62]. Brain metastatic tumor cells have shown high levels of $\alpha 4 ß 1$ integrin expression, suggesting a key role in metastatic seeding. Further, it has been shown that blocking overexpressed $\alpha 4 ß 1$ significantly diminishes the number of metastatic colonies within the brain, implying its potential as a therapeutic target [64]. In vitro assays have shown the involvement of $\alpha 4 \beta 1$ integrin cell adhesion to the vascular endothelium in melanoma, osteosarcoma and kidney cancer cells [65]. Its overexpression has further been detected in leukemia cells and lymphoma cells [66]. The expression of integrin $\alpha 4 ß 1$ by lymphoma cells may be partially responsive for metastasis of lymphomas to the bone marrow where marrow stomal cells express VCAM-1 $[66,67]$. In myeloma cells, myeloma cell adhesion to the bone marrow has been observed to be an $\alpha 4 \beta 1$ integrin-dependent process [68]. Moreover, it seems that $\alpha 4 ß 1$ expression may be a marker of poor prognosis in children with acute lymphoblastic leukaemia and may play an important role in the response to therapy [69]. It still needs to be determined whether it could be used as a therapeutic target.

In addition, oral squamous cell carcinoma cells make use of integrin $\alpha 4 ß 1$ to attach to endothelial cells in the metastatic process [70]. In ovarian cancer $\alpha 4 ß 1$ plays a role in mesothelial invasion [71], mesothelial invasion being an unfavorable prognostic marker [72]. $\alpha 4 ß 1$ as a therapeutic target was analyzed in a study by Scalici et al. [73]. Treatment of ovarian tumor-bearing mice with anti- $\alpha 4 ß 1$ antibodies alone had no effect, whilst combined treatment with carboplatin, human-specific $\alpha 4 ß 1$ blocking antibodies and anti-VCAM-1 antibody significantly reduced the tumor burden [73]. The involvement of integrin $\alpha 4 ß 1$ has also been observed in growth-factor and tumor-induced lymphangiogenesis promoting metastasis [74]. As it plays a part in lymphangiogenesis and metastasis, blocking this integrin may be useful in 
Table 1 Overview of adhesion molecules found on different leukocyte subtypes and their corresponding ligands

\begin{tabular}{|c|c|c|}
\hline Leukocyte Adhesion Molecule & Leukocyte Subtype & Ligand \\
\hline VLA-4 (a4ß1) & $\begin{array}{l}\text { Monocytes [39] } \\
\text { Neutrophils in case of sepsis [38] }\end{array}$ & $\begin{array}{l}\text { VCAM-1 } \\
\text { MAdCAM-1 } \\
\text { JAM-B }\end{array}$ \\
\hline LFA-1 (aLß2) (CD11a/CD18) & $\begin{array}{l}\text { Neutrophils [39, 42] } \\
\text { Monocytes [43] }\end{array}$ & $\begin{array}{l}\text { ICAM-1 } \\
\text { ICAM-2 } \\
\text { JAM-A }\end{array}$ \\
\hline a4ß7 (CD49d/B7) & $\begin{array}{l}\text { Lymphocytes (CD4 and CD8 T cells) } \\
\text { (mucosal lymphoid nodules) }[7,44]\end{array}$ & MAdCAM-1 \\
\hline $\begin{array}{l}\text { Gp150,95 (aXß2) } \\
\text { (CD11c/CD18) }\end{array}$ & $\begin{array}{l}\text { Monocytes } \\
\text { Macrophages [45] } \\
\text { Granulocytes [46] (Neutrophils [9]) } \\
\text { Langerhans cells }\end{array}$ & $\begin{array}{l}\text { iC3b } \\
(\text { JAM-C [47]) }\end{array}$ \\
\hline $\begin{array}{l}\text { aMß32 (mac-1) } \\
(\mathrm{CD} 11 \mathrm{~b} / \mathrm{CD} 18)\end{array}$ & $\begin{array}{l}\text { Monocytes [43] } \\
\text { Macrophages [45] } \\
\text { Granulocytes [48] } \\
\text { (Neutrophils [42]) } \\
\text { Langerhans cells [7] }\end{array}$ & $\begin{array}{l}\text { iC3b } \\
\text { ICAM-1 } \\
\text { ICAM-2 } \\
\text { JAM-C }\end{array}$ \\
\hline aDß2 & $\begin{array}{l}\text { Macrophages (?) [7] } \\
\text { Neutrophils [9] }\end{array}$ & ICAM-3 \\
\hline CD47 & T cell [49] & $\begin{array}{l}\text { VCAM-1 } \\
\text { ICAM-1 }\end{array}$ \\
\hline L1-CAM & Lymphocytes [4, 50, 51] & $\begin{array}{l}\text { a5ß1 (VLA-5) } \\
\text { aVB3 }\end{array}$ \\
\hline $\begin{array}{l}\text { Glycosylated proteins } \\
\text { (B-galactose) }\end{array}$ & Leukocytes [52] & Galectins \\
\hline
\end{tabular}

Only major ligands are listed

preventing metastatic spread. Moreover, integrin $\alpha 4 ß 1$ expression correlates with radiotherapy resistance in head and neck cancer [75]. It further mediates resistance to Lapatinib in breast cancer [76] and Erlotinib resistance in lung cancer cells [77].

In conclusion, the above-named results make imply that VLA-4 participates in the metastatic cascade by binding to VCAM-1 on the vascular endothelium (see Fig. 5), and its inhibition therefore may constitute a possible key element for the prevention of metastatic spread. However, it remains to be determined whether it could be used as a prognostic marker. Integrins $\alpha 9 ß 1$ and $\alpha D \beta 2$ have been described as alternative interaction partners for VCAM-1 [37] (see Table 3). It remains uncertain whether they are overexpressed on tumor cells, and this may be subject to analysis in the future.

\section{Integrin a5ß1 (VLA-5) and adhesion molecule L1-CAM}

Integrin $\alpha 5 ß 1$ (VLA-5), as well as $\alpha \mathrm{V} ß 3$ expressed on the vascular endothelium, interact with L1-CAM (neuronal cell adhesion molecule), a member of the immunoglobulin superfamily expressed on immune and neural cells [78-82]. With respect to its biological function, it has a static role as an adhesion molecule in cell-to-cell interaction and a motility-supporting role that drives cell migration during the development of the nervous system, and it also promotes metastatic dissemination [83-
86] (see Fig. 5). It is a transmembrane glycoprotein of the immunoglobulin superfamily that can interact with different binding partners heterophilically (eg. to integrins, other neural cell adhesion molecules, CD24 etc.), or even homophilically to itself [87]. Work over the past years has shown the significance of L1-CAM as a pro-metastatic factor (see Table 2). It is overexpressed in many different types of malignancies, such as colorectal carcinoma [88], melanoma [89], renal clear cell carcinoma [90], pancreatic ductal adenocarcinoma (PDAC) [85], breast cancer [88], ovarian and endometrial carcinoma [91]. Dissimilar to its function in neural development, L1-CAM expression in cancer induces a motile and invasive tumor phenotype, promoting metastatic dissemination, aggressive tumor expansion and chemoresistance associated with a poor prognostic outcome [87]. It seldom acts as a stimulus in cell-to-cell adhesion, as in neural development [87]. These attributes associated to L1-CAM expression will be illustrated subsequently. For cancer cells to become motile, the functional mode of L1-CAM needs to be altered. This is brought about by two mechanisms: the cleavage from the cell surface by membrane proximal proteolysis and the capacity to change ligands and get involved in L1-CAM integrin interactions. In tumor cell lines, cleavage of the membrane proximal L1-CAM ectodomain is mediated by disintegrin and metalloproteinases 
Table 2 Integrins expressed on leukocytes and tumor cells and their ligands

\begin{tabular}{|c|c|c|c|c|}
\hline Adhesion molecule & Family & Leukocyte subtype & Ligand & Expression on tumor cells \\
\hline $\begin{array}{l}\text { VLA-4 (a4ß1) } \\
\text { (CD49d) }\end{array}$ & Integrin & $\begin{array}{l}\text { Monocytes } \\
\text { Neutrophils in } \\
\text { case of sepsis }\end{array}$ & $\begin{array}{l}\text { VCAM-1 } \\
\text { MAdCAM-1 } \\
\text { JAM-B }\end{array}$ & $\begin{array}{l}\text { Melanoma, osteosarcoma, } \\
\text { kidney carcinoma, leukemia, } \\
\text { oral squamous cell carcinoma, } \\
\text { ovarian cancer }\end{array}$ \\
\hline $\begin{array}{l}\text { LFA-1 (aLß2) } \\
\text { (CD11a/CD18) }\end{array}$ & Integrin & $\begin{array}{l}\text { Neutrophils } \\
\text { Monocytes }\end{array}$ & $\begin{array}{l}\text { ICAM-1 } \\
\text { ICAM-2 } \\
\text { JAM-A }\end{array}$ & \\
\hline $\begin{array}{l}\text { Gp150,95 } \\
\text { (CD11c/CD18) }\end{array}$ & Integrin & $\begin{array}{l}\text { Monocytes } \\
\text { Macrophages } \\
\text { Granulocytes } \\
\text { Langerhans cells }\end{array}$ & $\begin{array}{l}\text { iC3b } \\
\text { JAM-C }\end{array}$ & \\
\hline $\begin{array}{l}\text { a4ß7 } \\
(\text { CD49d/B7) }\end{array}$ & Integrin & $\begin{array}{l}\text { Lymphocytes } \\
\text { (mucosal lymphoid } \\
\text { nodules) }\end{array}$ & MAdCAM-1 & \\
\hline $\begin{array}{l}\text { aMß2 (mac-1) } \\
\text { (CD11b/CD18) }\end{array}$ & Integrin & $\begin{array}{l}\text { Monocytes } \\
\text { Macrophages } \\
\text { Granulocytes } \\
\text { Langerhans cells }\end{array}$ & $\begin{array}{l}\text { iC3b } \\
\text { ICAM-1 } \\
\text { ICAM-2 } \\
\text { JAM-C }\end{array}$ & \\
\hline aDß2 & Integrin & Macrophages? & ICAM-3 & \\
\hline CD47 & & T cell & $\begin{array}{l}\text { VCAM-1 } \\
\text { ICAM-1 }\end{array}$ & \\
\hline ICAM-1 & Ig superfamily & $\begin{array}{l}\text { Monocytes } \\
\text { Epithelial cells } \\
\text { Fibroblasts }\end{array}$ & $\begin{array}{l}\text { LFA-1 (leukocytes) } \\
\text { Mac-1 (leukocytes)* }\end{array}$ & $\begin{array}{l}\text { Breast cancer, melanoma, } \\
\text { oral squamous carcinoma, } \\
\text { esophageal squamous } \\
\text { carcinoma, papillary thyroid } \\
\text { carcinoma, salivary adenoid } \\
\text { cystic carcinoma, gastric } \\
\text { cancer, non-small-cell lung } \\
\text { cancer, osteosarcoma, } \\
\text { prostate cancer }\end{array}$ \\
\hline $\begin{array}{l}\text { ICAM-2 } \\
\text { ICAM-3 }\end{array}$ & Ig superfamily & $\begin{array}{l}\text { Endothelial cells } \\
\text { Leukocytes } \\
\text { Langerhans cells }\end{array}$ & LFA-1 (CD11a) & \\
\hline VCAM-1 & Ig superfamily & $\begin{array}{l}\text { Activated endothelial } \\
\text { cells }\end{array}$ & VLA-4 & \\
\hline PECAM-1 & Ig superfamily & $\begin{array}{l}\text { Endothelial cells } \\
\text { Monocytes } \\
\text { Neutrophils }\end{array}$ & PECAM-1 (CD31) & \\
\hline MAdCAM-1 & Ig superfamily & Endothelial cells & $\begin{array}{l}\text { L-selectin } \\
\text { a4ß7 }\end{array}$ & \\
\hline L1-CAM & Ig superfamily & Tumor cells & $\begin{array}{l}\text { L1-CAM } \\
\text { a5ß1 } \\
\text { aVB3 (endothelium) }\end{array}$ & $\begin{array}{l}\text { Colorectal carcinoma, } \\
\text { epithelial ovarian carcinoma, } \\
\text { renal cell carcinoma, } \\
\text { melanoma, pancreatic ductal } \\
\text { adenocarcinoma, breast cancer }\end{array}$ \\
\hline aVß3 & Integrin & Tumor cells & L1-CAM & Prostate cancer, melanoma \\
\hline a5ß1 & Integrin & Tumor cells & L1-CAM & Breast cancer \\
\hline
\end{tabular}

CAMs in bold, have been identified on tumor cells (for references see text and table 1). *Leukocytes act as a bridge between tumor cell and the endothelium

(ADAMs) [87, 92]. Neoplastic cells cut homophilic adhesion molecules, converting them into mobile cells, thus allowing metastatic spread [93]. In addition, ectodomain cleavage appears to play a role in L1-CAM-mediated gene regulation of various cancer-related genes, which can promote a pro-tumorigenic and an anti-apoptotic gene expression pattern. Furthermore, the soluble ectodomain itself is functionally active stimulating cell migration [94], inhibiting apoptosis [95] and promoting angiogenesis $[87,96]$. On the one hand, motility is encouraged by the soluble L1-CAM ectodomain after cleavage, and on the other hand, by over expression of L1-CAM-promoting migration by enhancing L1-CAM- $ß 1$ integrin interactions [87]. Apart from $\alpha 5 ß 1$, L1-CAM interacts with RGD-binding integrins $\alpha \mathrm{V} ß 5$, $\alpha \mathrm{V} \beta 1, \alpha \mathrm{V} \beta 3$ and $\alpha \mathrm{IIb} 33$ [87]. As a binding partner for 
Table 3 Selection of integrin inhibitors in preclinical studies and clinical trials

\begin{tabular}{lll}
\hline Integrin Inhibitor & Target Integrin & Clinical trial \\
\hline Intetumumab (CNTO 95) & aV & Phase II [129] \\
$\begin{array}{l}\text { Abituzimab (DI17E6, } \\
\text { EMD 525797) }\end{array}$ & aV & Phase I/II [153] \\
MK-0429 & aVB3 & - \\
Cilengitide & aVB3 & Phase II/II [135, 137] \\
(EMD 121974) & aVB5 & \\
D-pinitol & aVB3 & - \\
GLPG0187 & aVB3 & Phase I [144] \\
Volociximab (M200) & a5B1 & Phase II [148] \\
PF-04605412 & a5B1 & Phase I [149] \\
\hline
\end{tabular}

L1-CAM, $\alpha 5 ß 1$ Integrin (VLA-5) is allegedly found on the vascular endothelium and functions as an adhesion molecule in tumor cell extravasation [80]. One may assume that by expressing L1-CAM, the tumor cell may gain the key to a lock on its metastatic journey, allowing substantial progress, even if it may not remain the only lock to be opened on its way.

L1-CAM overexpression was first described in colon cancer cell lines with aberrantly activated $ß$-catenin-T-cell factor (TCF) signaling. The promoter of the L1-CAM gene is activated by the $B$-catenin-TCF pathway $[88,89]$. In addition, L1-CAM expression correlates with metalloprotease ADAM10 expression, driving L1-CAM to become functional [88]. A fact supporting the hypothesis of L1-CAM as a promoter of the induction of a motile tumorigenic phenotype is its known role in cell migration during the development of the nervous system. L1-CAM and ADAM10 have been found at the invasive front of colorectal cancers [88]. Furthermore, a study revealed L1-CAM expression in 13\% of colorectal cancer patients who underwent surgical resection [97]. Analysis of L1-CAM expression unveiled a significant correlation of L1 expression, with the dissemination of tumor cells in lymph nodes and bone marrow. In addition, comparison of survival in L1-CAM-positive and -negative patients retrospectively revealed a significantly poorer outcome for positive L1-CAM patients; five-year overall survival was decreased by $20 \%$ [97]. Another study determined L1 expression in colorectal carcinoma to be $10.9 \%$, and it was significantly associated with distant metastasis [98]. Additionally, L1-CAM expressing colon cancer cells, when injected into the spleen of mice, promote the spread of tumor cells forming liver metastasis [99]. These findings suggest that L1-CAM expression may have a prognostic value in colorectal carcinoma, and further exploration is required into whether it may be used as a prognostic marker.

L1-CAM is upregulated in ovarian and uterine carcinomas, and its expression is associated with adverse outcome in terms of short survival [91]. In these tumor entities, first results suggest that L1-CAM expression may be used as a prognostic marker, and it could be of aid to identify patients with uterine cancer who are at high risk for recurrent disease [91]. L1-CAM expression patterns in epithelial ovarian carcinoma have been analyzed. The normal ovarian surface epithelium shows a specific expression pattern of L1-CAM, whilst the highly invasive epithelial ovarian carcinoma cells display an enriched pattern, suggesting its role in neoplastic transformation [100]. Furthermore, expression was significantly associated with poor outcome and a more invasive cancer phenotype. It has been shown that L1-CAM plays a dual role in ovarian surface epithelial cells, supporting a tumor-suppressive function in non-transformed cells on one hand; and on the other hand promoting invasion in ovarian cancer cells by the means of a functional-switch and an increase in its expression [100]. These results imply that L1-CAM may represent a therapeutic target and should therefore be explored. L1-CAM overexpression has been found in $46 \%$ of clear cell renal carcinoma and in $28 \%$ of papillary renal cell carcinoma [89]. Expression significantly correlated with the Ki-67 proliferation index [89]. In renal clear cell carcinoma, its presence was further associated with metastatic spread, the risk being greater if cyclin $\mathrm{D}$ was not expressed in the cancer cells [90]. The L1-CAM +/cyclin D- profile was found to be a prognostic factor for the presence of metastasis [90].

Additionally, $42 \%$ of malignant melanoma tissues show L1-CAM presence [89]. Its expression has been associated with sustained activation of the extracellular signal-regulated kinase (ERK) pathway, resulting in an upregulation of gene products such as $\alpha \mathrm{V} ß 3$ integrin, thus mediating a motile tumor phenotype [101]. The correlation of L1-CAM expression with melanoma progression and migration is significant [101], and upregulation has been associated with metastasis [102]. Overexpression further induces conversion of the radial melanoma growth phase to the vertical growth phase, representing a more invasive phenotype [101]. L1-CAM function suppression significantly reduces invasive growth, but it did not completely block melanoma invasion and migration. Meier et al. additionally analyzed different function-blocking antibodies of L1. Their findings acknowledge L1-CAM as an important player in melanoma invasion and progression, and they recognized its therapeutic potential, especially in combination with conventional cancer treatment, although blockage of L1 alone may not be enough to cease or reverse invasive growth [101]. In pancreatic ductal adenocarcinoma (PDAC), L1-CAM expression was found in $80 \%$ of patients [85], while other studies showed focal L1-CAM expression in 2\% [103]. Expression seems to be involved in anti-apoptotic protection and chemoresistance. The transformation to a chemoresistant pancreatic ductal 
adenocarcinoma phenotype involves an increased IL-B-dependent secretion of nitric oxide (NO) and the engagement of L1-CAM. High IL-ß-dependent L1-CAM expression conferred anti-apoptotic protection to cancer therapy agents in neoplastic cells [85]. Apart from PDAC, L1-CAM overexpression is linked to a more motile phenotype of breast cancer cells [89]. On one hand, L1-CAM expression is downregulated by $\mathrm{Nm} 23-\mathrm{H} 1$ (metastasis suppressor gene) mediating non-metastatic breast cancer cells; on the other hand, cells lacking Nm23-H1 had high L1-CAM levels and a more motile phenotype [104].

We have seen that L1-CAM expression is detected in various cancer entities (see Table 2) and its expression most significantly correlated with tumor progression, invasion and metastatic spread. It has also been associated with chemoresistance [85] and may be used as a prognostic marker in some cases $[90,91]$. As a key player in the metastatic pathway of different tumors, its value as a potential therapeutic target becomes more and more evident.

\section{Integrins $a V B 3$ and $\alpha 5 ß 1$}

Apart from L1-CAM expression being observed on tumor cells, the expression of its ligands $\alpha \mathrm{V} \beta 3$ and $\alpha 5 \beta 1$ has been observed $[105,106]$ (see Fig. 5). These integrins bind to L1-CAM found on endothelial cells and mediate a more invasive tumor cell phenotype. A non-neuronal form of L1-CAM is also found on epithelial cells [107]. Integrin $\alpha 5 ß 1$, as an interaction partner for L1-CAM, has been discovered to be implicated in glycoprotein nmb-mediated (GPNMB) breast cancer progression [106] (see Table 2). In contrast, integrin $\alpha \mathrm{V} ß 3$, representing a binding partner for L1-CAM, is expressed on various types of tumor cells. The integrin $\alpha \mathrm{V} ß 3$ is involved in angiogenesis, neovascularization and tumor metastasis [108] (see Table 2). Investigations of the expression of $\alpha \mathrm{V} \beta 3$ on prostate cancer cells has been highly contradictory. It has been indicated that prostate cancer cells use $\alpha \mathrm{V} \beta 3$ to stimulate angiogenesis and thereby facilitate growth and metastasis [105]. Furthermore, Cooper et al. attributed integrin $\alpha \mathrm{V} ß 3$ a role in the adhesion of prostate cancer cells to the endothelium and in the metastatic dissemination to the bone through a PI-3 kinase / Akt pathway [105]. Nevertheless, other investigations show that most prostate tumor cells are immunonegative for $\alpha \mathrm{V} ß 3[109,110]$. These controversial findings will need further clarification.

In addition, $\alpha \mathrm{V} ß 3$ has been found to be involved in the progression of the radial growth phase melanoma towards the invasive vertical growth phase melanoma $[111,112]$. The expression is low or absent in the radial growth phase [113]. Once the tumor cells upregulate the ß3 integrin expression, tumor thickness increases and the melanoma cells gain the capacity to invade, spread and colonize distant organs $[111,113]$. In a similar manner, the overexpression of $\alpha 4 ß 1$ integrin leads to the more invasive phenotype of melanoma tumor cells and seems to have an effect on the metastatic potential of melanoma cells [112, 114]. Essential for metastatic spread is transendothelial migration of the tumor cells; for this process melanoma cells make use of $\alpha \mathrm{V} \beta 3$ integrin [113]. As stated earlier, the melanoma cells lacking $\alpha \mathrm{V} ß 3$ integrins can make use of $\beta 1$ integrins instead to adhere to the endothelial ligand VCAM-1 [112]. The integrin $\alpha 4 \beta 1$ is only found on highly metastatic melanoma cell lines such as MV3 and BLM [115].

\section{Integrins as therapeutic targets}

As illustrated above, carcinoma cells express numerous integrins mediating the adhesion to the vascular endothelium and thereby promoting extravasation and metastasis. Therefore, the pharmacological inhibition of these integrins could represent a way of slowing down or even stopping cancer progression.

Integrins represent a therapeutic target for antibody-based drugs (most abundant integrin targeting drugs), small-molecule-based drugs and peptide-based drugs [112]. Further, first data reveals that targeting integrins using chimeric antigen receptor-engineered T-cells might as well be of use in T cell immunotherapy of solid tumors [116]. In the last years several integrin-targeted drugs are showing promising results in preclinical studies, others have advanced to clinical trials and some have been approved for clinical use [117]. Nineteen of the 24 integrin heterodimers have been therapeutic targets for new pharmacological agents [118]. Presently, there are some pharmaceutics targeting $\alpha I I b ß 3$ integrin to prevent platelet aggregation in percutaneous cardiac intervention, acute coronary syndromes and myocardial infarction, approved by the U.S. Food and Drug Administration (FDA) [117]. Furthermore, there is one FDA approved $\alpha 4$ antagonist named Natalizumab for the treatment of multiple sclerosis and Crohn's disease, binding $\alpha 4 \beta 1$ and $\alpha 4 \beta 7$ [117]. To date, there are no FDA-approved $\alpha \mathrm{V} \beta 3$ and $\alpha \mathrm{V} \beta 5$ integrin antagonists as well as $\alpha 5 ß 1$ integrin antagonists, although some are under evaluation in clinical trials for the treatment of inflammatory and neoplastic diseases $[117,119]$.

Intetumumab (CNTO 95), a human anti- $\alpha \mathrm{V}$ integrin antibody, inhibits melanoma cell adhesion, migration and invasion in vitro and decreases tumor growth in melanoma xenografts in mice [112, 120]. It is currently evaluated by a randomized, phase II study [121]. Orally active $\alpha \mathrm{V} ß 3$ integrin inhibitor MK-0429 reduced lung metastasis and melanoma burden in the mouse model [122]. MK-0429 was also evaluated in patients with hormone-refractory prostate cancer and bone metastasis 
[123]. It was generally well tolerated and there was some evidence of reduction of osteoclast activity, indicating a potential for clinical use in the treatment of hormone-refractory prostate cancer, eventhough serum prostatic specific antigen (PSA) was unexpectedly increased during the trial $[123,124]$. A randomized phase II study of Etaracizumab, a monoclonal antibody against $\alpha \mathrm{V} ß 3, \pm$ dacarbazine in patients with stage IV metastatic melanoma, showed no improvement in survival over decarbazine alone [125] (see Table 3). Another selective inhibitor of the integrins $\alpha \mathrm{V} \beta 3$ and $\alpha \mathrm{V} \beta 5$ is Cilengitide (EMD 121974) $[112,126]$. On one hand, a randomized phase II study in patients with metastatic melanoma showed good tolerance. On the other hand, Cilengitide only showed minimal clinical efficacy as monotherapy in metastatic melanoma [127]. In addition, Cilengitide is being evaluated for the treatment of other neoplastic diseases. In an osteosarcoma mouse model it inhibited pulmonary metastasis and minimally decreased primary tumor growth [128]. Its anti-angiogenic and anti-metastatic functions have also been assessed in a phase III clinical trial for glioblastoma multiforme therapy [129]. The lack of efficacy in this trial was a surprise and discouragement [130]. Although some studies are still ongoing and their results pending, up to date, all clinical trials evaluating $\alpha \mathrm{V} \beta 3$ and $\alpha \mathrm{V} \beta 5$ inhibitor Cilengitide, amongst others in squamous cell carcinoma of the head and neck, glioblastoma and non-small cell lung carcinoma, have failed their primary endpoints [118] (see Table 3). The overall results and the detailed revision of these trials will decide whether $\alpha \mathrm{V} \beta 3$ and $\alpha \mathrm{V} \beta 5$ integrin antagonists might yet become an effective therapy and make their way to clinical use in oncologic treatment.

Abituzimab (DI17E6, EMD525797), a humanized monoclonal antibody against integrins containing an $\alpha \mathrm{V}$-subunit, inhibited migration and invasion of prostate cancer cells in a preclinical model [131]. In a multicenter phase 1 trial in advanced prostate cancer with bone metastases there was evidence for clinical activity, which needs to be confirmed in the phase II trial [132]. Abituzumab is further investigated in metastatic colorectal cancer (phase I/II POSEIDON trial), although the primary end point was not reached, biomarker analyses revealed subgroups of patients whom may have benefited [133] (see Table 3). Further, integrin $\alpha \mathrm{V} ß 3$ inhibitors are being studied for the treatment of prostate cancer [124]. An analysis revealed anti-metastatic effects of D-pinitol, a phytochemical, in human prostate cancer cells by reducing the cell surface expression of $\alpha \mathrm{V} \beta 3$ integrin. Further, D-pinitol modulated FAK, $\mathrm{c}-\mathrm{Src}$ and NF-kB pathways leading to an added inhibition of $\alpha \mathrm{V} \beta 3$ integrin [134]. Other preclinical models of prostate cancer demonstrated that the inhibition of $\alpha \mathrm{V}$-integrins, in particular $\alpha \mathrm{V} ß 3$ integrin, by GLPG0187, a broad spectrum integrin receptor antagonist, reduced de novo formation as well as progression of bone metastases in prostate cancer [135]. A phase I study of GLPG0187 in patients with advanced solid malignancies failed to demonstrate signs of single-agent therapy efficacy [136] (see Table 3). However, other experimental investigations suggest that $\alpha \mathrm{V} \beta 3$ does not play an important role in the adhesion of prostate cancer cells and its blockage causes no observable effect on the number of adhered cells [137], which could explain the failure in efficacy of $\alpha \mathrm{V} \beta 3$-antagonists in phase I and II trials. These controversial findings should be subject to further clarification. In the same analysis blocking $\alpha 5 ß 1$ integrin, instead of $\alpha \mathrm{V} ß 3$, reduced the number of adherent prostate cancer cells [137]. Similar to the results obtained in studies evaluating $\alpha \mathrm{V} \beta 3$-antagonists, the inhibition of integrin $\alpha \mathrm{V} ß 3$ has had little therapeutic effect in several trials for solid tumors [118]. Raab-Westphal et al. suggest that the controversy between preclinical and clinical data may result partly from the fact that xenograft models do not reflect human tumors genetically, nor with respect to pharmacokinetic and pharmacodynamics behavior, well enough [118]. Furthermore, some data indicates that $\alpha \mathrm{V} \beta 3$ and $\alpha \mathrm{V} \beta 5$ integrins are not essential for angiogenesis and pathological vascular development apparently reversing the previously widely reported and suggested importance of the integrins for angiogenesis [138]. These conflicting results only highlight the need for further evaluation.

Volociximab (M200), a $\alpha 5 ß 1$ integrin inhibitor, has displayed promising results in preclinical and clinical trials [112, 139]. It is being evaluated for monotherapy and combined treatments in different tumor entities such as metastatic melanoma [112], ovarian and peritoneal cancer [140]. In a phase II study in patients with ovarian or peritoneal cancer Volociximab showed insufficient clinical activity [140] (see Table 3). A different $\alpha 5 ß 1$ integrin antagonist, integrin monoclonal antibody PF-04605412, demonstrated no anti-tumor activity too in a first-in-human clinical trial, leading to a discontinuation of its clinical development [141]. The N-terminus of the ß1-domain of integrin $\alpha 5 ß 1$ also represents a target for ATN-161, a small peptide, which inactivates the integrin [142]. In mice, the combined treatment with $\alpha 5 ß 1$-inhibitor ATN-161 and chemotherapeutic 5-fluorouracil (5-FU) diminished colorectal liver metastases, reduced angiogenesis and improved survival [142]. In a phase I trial of ATN-161 in patients with solid tumors, about $1 / 3$ of the patients that administered ATN-161 displayed prolonged stable disease and different dose levels were well tolerated [143] (see Table 3). Some more recent preclinical studies of targeted chemotherapy of $\alpha 5 ß 1$ integrin positive solid tumors show 
promising antitumor effects in vitro and in vivo in mice, that appear encouraging for further investigation [144].

Although many preclinical trials show promising results, most clinical trials evaluating integrin inhibitors in neoplastic disease have failed to meet the expectations as anti-tumor agents. Nevertheless, the use of integrin-targeting drugs in thrombosis prevention after percutaneous coronary intervention (PCI) ( $\alpha I I b ß 3$ integrin), ulcerative colitis, Crohn' disease and multiple sclerosis ( $\alpha 4 \beta 1$ and $\alpha 4 \beta 7$ integrins) [145] show that integrins do represent a potential therapeutic target and may show clinical efficacy in metastases prevention henceforth. It may only be necessary for some reevaluation to take place to be able to overcome the gap between preclinical and clinical trial results and achieve the desired tumor control in the future. Hereafter some problems in relation to integrin inhibitors will be discussed.

Cells express multiple integrins and other adhesion molecules [146]. Integrins retain redundancy in ligand interaction and signaling functions, and there is extensive crosstalk between integrins affecting cell functions [147]. A form of integrin-crosstalk, trans-dominant inhibition of integrin activation, takes place when ligand binding to one integrin inhibits the activity of another integrin [147]. This implies that blocking one integrin may only lead to the upregulation of another related integrin, rather than inhibiting a complete signaling pathway, to maintain adhesion, interaction and signaling. Additionally, a highly selective antagonist of a single integrin may make the development of resistance or paradoxical effects more likely [146]. Sheldrake and Patterson have characterized the potential of dual and multi-integrin-antagonists as more efficient inhibitors of cancer progression and dissemination [146]. It seems plausible that the inhibition of a single integrin may not suppress the complete adhesive cell function in a cell that expresses a pattern of different integrins. Apart from dual and multi-integrin inhibitors, the combination of integrin antagonists with other drugs with anti-tumor activity such as chemotherapeutics are being evaluated [142, 148]. An integrin inhibitor could intensify and reinforce the anti-tumor effect of an oncologic treatment, rather than be used as a single-agent.

A different reason for the failure of single integrin inhibitors in stopping cancer cell dissemination and slowing down disease progression might be the fact that selectin interactions come first and are not altered by integrin antagonists. Apart from using integrin mediated adhesion, ovarian cancer cells predominantly employ selectin-dependent leukocyte-like adhesion cascades in peritoneal spread [149]. These cascades have also been observed in peritoneal metastasis of pancreatic adenocarcinoma [150]. These selectin-dependent cascades might not be altered at all or enough by integrin antagonists to prevent the extravasation of cancer cells.
How integrin inhibitors may interfere with the integrins physiological function, is another issue to be discussed and reviewed. Genetic and cell biological analysis has revealed a number of different integrin functions [151]. However, integrins do not simply act as glue-like molecules; they constitute bi-directional signaling receptors involved in outside-in and inside-out signaling [31, 152]. As cell surface receptors integrins coordinate the assembly of cytoskeletal polymers and signaling complexes on the cytoplasmatic face of the plasma membrane [37, 151]. On the extracellular face integrins interact with extracellular matrix substrates or counterreceptors on cell surfaces, allowing cell-to-matrix and cell-to-cell linkages [31]. These interactions are essential for cell migration by supplying traction to migrating cells and by transferring guidance signals that direct moving cells and their targets [151]. Cell migration being of great significance in developmental processes [153] and in cell extravasation during inflammatory response [4]. Further, cell-to-cell interaction, integrin-mediated adhesion, embodies a key role in tissue integrity and is of particular importance permitting tissues to withstand mechanical load [151]. Additionally, integrins contribute to tissue differentiation and organogenesis [151]. The abundancy of functions and occurrence of integrins implies distinct potential side effects their inhibition could involve. Nevertheless, one must keep in mind that various phase I studies focusing on toxicity of integrin inhibitors have shown good tolerance and no major adverse events [121, 127, 143].

\section{Conclusion}

In conclusion, various integrins have been reported to be overexpressed in cancer cells, promoting a more motile and invasive phenotype (see Fig. 5, Table 2). It remains unknown whether tumor cells express an even greater range of adhesion molecules as has yet been described. The specification and exploration of possible alternative adhesion molecules on tumor cells for known ligands (see Table 4) may be of interest in the definitive and more detailed characterization of the tumor cell integrin expression pattern. This is due to the fact that tumor cells, even when imitating leukocyte mechanisms for extravasation, do not express the exact same adhesion molecule patterns as leukocytes. Table 4 shows alternative adhesion molecules tumor cells could express, instead of the integrins found on leukocytes, to bind to endothelium. A definitive characterization of the integrin expression pattern of tumor cells may give new insights and answers to the question why some integrin inhibitors aren't showing the expected positive results in clinical trials. In addition, it may open up possibilities for combined integrin inhibitor therapies. 
Table 4 Alternative adhesion molecules

\begin{tabular}{|c|c|c|}
\hline $\begin{array}{l}\text { Leukocyte Adhesion } \\
\text { Molecule }\end{array}$ & $\begin{array}{l}\text { Alternative Adhesion } \\
\text { Molecule }\end{array}$ & Ligand \\
\hline VLA-4 (a4ß1) & $\begin{array}{l}a 4 ß 7 \\
a 9 ß 1 \\
a D ß 2\end{array}$ & VCAM-1 \\
\hline VLA-4 (a4ß1) & $a 4 ß 7$ & $\begin{array}{l}\text { MAdCAM- } \\
1\end{array}$ \\
\hline$a 4 ß 7$ & $a 4 ß 1$ & $\begin{array}{l}\text { MAdCAM- } \\
1\end{array}$ \\
\hline LFA-1 (aLß2) & $\begin{array}{l}\text { aXß2 } \\
\text { aMß2 } \\
\text { aDß2 }\end{array}$ & ICAM \\
\hline Gp150,95 & $\begin{array}{l}\text { aXß2 } \\
\text { aMß2 }\end{array}$ & iC3b \\
\hline L1-CAM & $\begin{array}{l}\operatorname{aVB1^{a}} \\
\operatorname{allBB3}^{a}\end{array}$ & $\begin{array}{l}\text { a5ß1 } \\
\text { aVB3 }\end{array}$ \\
\hline
\end{tabular}

${ }^{a}$ aVß1 and allBß3 as possible alternative adhesion molecules bind to L1-CAM and therefore could only be of use for tumor cells to bind to leukocytes mediating adhesion to the endothelium as linker cells

The table shows alternative adhesion molecules (Humphries et al. 2006) tumor cells could use instead of the adhesion molecules present on leukocytes to adhere to the vascular endothelium for extravasation

In many tumor entities, high levels of integrin/integrin ligand expression correlate with cancer progression, invasion and metastasis. First studies suggest that integrin expression patterns may have prognostic value and that they may be used to identify patients at high risk of adverse outcome in risk stratification [91]. Nevertheless, sufficient evidence still needs to be revealed. Apart from having a prognostic value, they might be of use in imaging. Integrins represent a target for selective imaging agents that might allow detection of metastases [154, 155]. Principally, they represent a potential therapeutic target and their blockade could be a way of preventing distant organ seeding. To understand the implications the discovery of a new therapeutic alternative could have, one must keep in mind that metastatic dissemination constitutes one of the major challenges in oncologic treatment. In many patient histories, metastases transform a disease considered curative into a palliatively approached one. The variety of integrins found upregulated on tumor cells gives cause to doubt whether blocking a single integrin could represent a promising way of stopping metastatic spread. It is more likely that to achieve the desired effect, whole integrin patterns will have to be inhibited to minimize extravasation, the phenotypic transformation and angiogenesis. Furthermore, it needs to be elaborated in greater detail to what extent such a blockade would interfere with the integrins' physiological function in the body, such as leukocyte extravasation or any other cell-to-cell or cell-to-matrix interaction [27]. Nevertheless, once the gap between reassuring preclinical studies $[101,122]$ and the corresponding less encouraging clinical trials has been overcome, integrins could open up a new range of therapeutic possibilities in oncologic treatment. This step forwards could be brought about by new approaches towards integrin inhibitors, such as combined therapies [146] and the knowledge gain through results of evolving trials and evaluations. Ongoing and future clinical trials will decide whether integrin antagonists make their way into clinical use or not.

It still remains to be determined whether targeting integrins may bring us one step closer to defeating metastatic spread, one of the biggest dilemmas in advanced cancer stages, and whether these adhesion molecules have the potential for a major breakthrough in oncologic treatment.

\section{Abbreviations \\ ADAM: A disintegrin and metalloproteinase; ADMIDAS: Adjacent to MIDAS; CAM: Cell adhesion molecule; CEA: Carcinoembryonic antigen; \\ CLA: Cutaneous lymphocyte antigen; FDA: U.S. Food and Drug \\ Administration; EMT: Epithelial mesenchymal transition; ERK: Extracellular signal-regulated kinase; ESCC: Esophageal squamous cell carcinoma; GPNMB: Glycoprotein nmb-mediated; HCELL: Hematopoietic cell E-/L- selectin ligand; HEV: High endothelial venules; IAC: Integrin adhesion complex; ICAM: Intercellular adhesion molecule; JAM-A, B, C: Junctional adhesion molecule A, B, C; LFA-1: Lymphocyte function associated antigen 1; L1-CAM: Neuronal cell adhesion molecule; MET: Mesenchymal-epithelial transition; MIDAS: Metal-ion-dependent adhesion site; PCI: Percutaneous coronary intervention; PDAC: Pancreatic ductal adenocarcinoma; PMN: Polymorphonuclear neutrophils; PSA: Prostatic specific antigen; PSGL- 1: P-selectin glycoprotein ligand-1; TCF: T-cell factor; VCAM-1: Vascular cellular adhesion molecule; VLA-4: Very late antigen 4; 5-FU: 5-fluorouracil}

\section{Acknowledgements}

My sincere thanks go to my supervisor, Prof. Dr. Schumacher, for his patience, support and encouragement. I am very grateful for the opportunity he has given me. Without his help, this work wouldn't have been possible. We thank Ms. Liz Grundy for her English language editing and proofreading.

\section{Funding}

None.

\section{Availability of data and materials}

Not applicable.

\section{Authors' contributions}

GS wrote the initial manuscript and US edited it. All authors read and approved the final manuscript.

Ethics approval and consent to participate

Not applicable.

Consent for publication

Not applicable.

Competing interests

The authors declare that they have no competing interests.

\section{Publisher's Note}

Springer Nature remains neutral with regard to jurisdictional claims in published maps and institutional affiliations.

Received: 22 May 2018 Accepted: 27 December 2018

Published online: 18 January 2019

\section{References}

1. Vogelstein B, Kinzler KW. The path to cancer - three strikes and You're out. N Engl J Med. 2015;373:1895-8. 
2. Valastyan S, Weinberg RA. Tumor metastasis: molecular insights and evolving paradigms. Cell. 2011;147:275-92.

3. Thiery JP, Acloque H, Huang RYJ, Nieto MA. Epithelial-mesenchymal transitions in development and disease. Cell. 2009;139:871-90.

4. Strell C, Entschladen F. Extravasation of leukocytes in comparison to tumor cells. Cell Commun Signal. 2008;6:10. https://doi.org/10.1186/1478-811X-6-10.

5. Qi J, Chen N, Wang J, Siu CH. Transendothelial migration of melanoma cells involves $\mathrm{N}$-cadherin-mediated adhesion and activation of the beta-catenin signaling pathway. Mol Biol Cell. 2005;16:4386-97.

6. Barthel SR, Gavino JD, Descheny L, Dimitroff CJ. Targeting selectins and selectin ligands in inflammation and cancer. Expert Opin Ther Targets. 2008; 11:1473-91.

7. Elangbam CS, C. W., Qualls J, Dahlgren RR. Cell adhesion molecules — update. Vet Pathol. 1997;34:61-73.

8. Sackstein R. The bone marrow is akin to skin : HCELL and the biology of hematopoietic stem cell homing. Med Sci. 2004;122:1061-9.

9. Kelly $M$, Hwang JM, Kubes P. Modulating leukocyte recruitment in inflammation. J Allergy Clin Immunol. 2007;120:3-10.

10. Witz IP. The involvement of selectins and their ligands in tumor-progression. Immunol Lett. 2006;104:89-93.

11. Krause T, Turner GA. Are selectins involved in metastasis? Clin Exp Metastasis. 1999;17:183-92.

12. Tremblay P, Auger FA, Huot J. Regulation of transendothelial migration of colon cancer cells by E-selectin-mediated activation of p38 and ERK MAP kinases. Oncogene. 2006;25:6563-73.

13. Burdick MM, Chu JT, Godar S, Sackstein R. HCELL is the major E- and Lselectin ligand expressed on LS174T colon carcinoma cells. J Biol Chem. 2006;281:13899-905.

14. Hanley WD, Napier SL, Burdick MM, Schnaar RL, Sackstein R, Konstantopoulos K. Variant isoforms of CD44 are P-and L-selectin ligands on colon carcinoma cells. FASEB J. 2006;20:337-9.

15. Laferrière J, Houle F, Huot J. Adhesion of HT-29 colon carcinoma cells to endothelial cells requires sequential events involving E-selectin and integrin 34. Clin Exp Metastasis. 2004;21:257-64.

16. Flugy AM, D'Amato M, Russo D, Di Bella MA, Alaimo G, Kohn EC, et al. Eselectin modulates the malignant properties of T84 colon carcinoma cells. Biochem Biophys Res Commun. 2002;293:1099-106.

17. Thomas SN, Zhu F, Schnaar RL, Alves CS, Konstantopoulos K. Carcinoembryonic antigen and CD44 variant isoforms cooperate to mediate colon carcinoma cell adhesion to $\mathrm{E}$ - and L-selectin in shear flow. J Biol Chem. 2008;283:15647-55.

18. Dimitroff CJ, Lechpammer M, Long-Woodward D, Kutok JL. Rolling of human bone-metastatic prostate tumor cells on human bone marrow endothelium under shear flow is mediated by E-selectin. Cancer Res. 2004; 64:5261-9

19. Dimitroff CJ, Descheny L, Trujillo N, Kim R, Nguyen V, Huang W, et al. Identification of leukocyte E-selectin ligands, P-selectin glycoprotein Ligand1 and E-selectin Ligand-1, on human metastatic prostate tumor cells. Cancer Res. 2005:65:5750-60.

20. Aigner S, Ramos CL, Hafezi-moghadam A, Lawrence MB, Friederichs J, Altevogt P, et al. CD24 mediates rolling of breast carcinoma cells on Pselectin. FASEB J. 1998;12:1241-51.

21. Tözeren A, Kleinman HK, Grant DS, Morales D, Mercurio AM, Byers SW. Eselectin-mediated dynamic interactions of breast-and colon-cancer cells with endothelial-cell monolayers. Int J Cancer. 2018;60:426-31.

22. Martín-Satué M, Marrugat R, Cancelas JA, Blanco J. Enhanced expression of $a(1,3)$-fucosyltransferase genes correlates with E-selectin-mediated adhesion and metastatic potential of human lung adenocarcinoma cells. Cancer Res. 1998;58:1544-50

23. Iwai $\mathrm{K}$, Ishikura $H$, Kaji M, Sugiura $H$, Ishizu A, Takahashi C, et al. Importance of E-selectin (ELAM-1) and sialyl Lewis(a) in the adhesion of pancreatic carcinoma cells to activated endothelium. Int J Cancer. 2018;54:972-7.

24. Kawashima $\mathrm{H}$. Roles of sulfated glycans in lymphocyte homing. Biol Pharm Bull. 2006:29:2343-9.

25. Läubli H, Stevenson JL, Varki A, Varki NM, Borsig L. L-selectin facilitation of metastasis involves temporal induction of Fut7-dependent ligands at sites of tumor cell arrest. Cancer Res. 2006;66:1536-42.

26. Strell C, Lang K, Niggemann B, Zaenker KS, Entschladen F. Surface molecules regulating rolling and adhesion to endothelium of neutrophil granulocytes and MDA-MB-468 breast carcinoma cells and their interaction. Cell Mol Life Sci. 2007;64:3306-16.
27. Plow EF, Haas TA, Zhang L, Loftus J, Smith JW. Ligand binding to integrins. J Biol Chem. 2000;21:21785-8.

28. Horton ER, Humphries JD, James J, Jones MC, Askari JA, Humphries MJ. The integrin adhesome network at a glance. J Cell Sci. 2016;129:4159-63.

29. Hynes RO. Integrins: bidirectional, allosteric signaling machines. Cell. 2002; 110:673-87.

30. Hynes RO. The emergence of integrins: a personal and historical perspective. Matrix Biol. 2004;23:333-40.

31. Barczyk M, Carracedo S, Gullberg D. Integrins. Cell Tissue Res. 2010;339:269-80.

32. Lee JO, Bankston LA, Robert C, MAA L. Two conformations of the integrin A-domain (I-domain): a pathway for activation? Structure. 1995;3:1333-40.

33. Larson RS, Corbi AL, Berman L, Springer T. Primary structure of the leukocyte function-associated molecule-1a subunit: an integrin with an embedded domain defining a protein superfamily. J Cell Biol. 1989;108:703-12.

34. Harris ES, Mclntyre TM, Prescott SM, Zimmerman GA. The leukocyte integrins. J Biol Chem. 2000;275:23409-12.

35. Campbell ID, Humphries MJ. Integrin structure, activation, and interactions. Cold Spring Harb Perspect Biol. 2011;3:1-14.

36. Humphries MJ. The molecular basis and specificity of integrin-ligand interactions. J Cell Sci. 1990;97:585-92.

37. Humphries JD, Byron A, Humphries MJ. Integrin ligands at a glance. J Cell Sci. 2006;119:3901-3.

38. Ibbotson GC, Doig C, Kaur J, Gill V, Ostrovsky L, Fairhead T, et al. Functional alpha4-integrin: a newly identified pathway of neutrophil recruitment in critically ill septic patients. Nat Med. 2001;7:465-70.

39. Schnoor M, Alcaide P, Voisin MB, Van Buul JD. Crossing the vascular wall: common and unique mechanisms exploited by different leukocyte subsets during extravasation. Mediat Inflamm. 2015;2015:946509. https:/doi.org/10.1155/ 2015/946509.

40. Sallusto F, Baggiolini M. Chemokines and leukocyte traffic. Nat Immunol. 2008:9:949-52.

41. Sigmundsdottir $\mathrm{H}$, Butcher EC. Environmental cues, dendritic cells and the programming of tissue-selective lymphocyte trafficking. Nat Immunol. 2008;9:981-7.

42. Simon Sl, Hu Y, Vestweber D, Smith CW. Neutrophil tethering on E-selectin activates beta 2 integrin binding to ICAM-1 through a mitogen-activated protein kinase signal transduction pathway. J Immunol. 2000;164:4348-58.

43. Reiss Y, Engelhardt B. T cell interaction with ICAM-1-deficient endothelium in vitro: transendothelial migration of different $\mathrm{T}$ cell populations is mediated by endothelial ICAM-1 and ICAM-2. Int Immunol. 1999;11:1527-39.

44. Ostermann G, Weber KSC, Zernecke A, Schröder A, Weber C. JAM-1 is a ligand of the $\beta 2$ integrin LFA-1 involved in transendothelial migration of leukocytes. Nat Immunol. 2002;3:151-8.

45. Imhof BA, Aurrand-Lions M. Adhesion mechanisms regulating the migration of monocytes. Nat Rev Immunol. 2004;4:432-44.

46. Ley K, Laudanna C, Cybulsky MI, Nourshargh S. Getting to the site of inflammation: the leukocyte adhesion cascade updated. Nat Rev Immunol. 2007;7:678-89.

47. Kammerer S, Roth RB, Reneland R, Marnellos G, Hoyal CR, Markward NJ, et al. Large-scale association study identifies ICAM gene region as breast and prostate cancer susceptibility locus. Cancer Res. 2004;64:8906-10.

48. Rosette C, Roth RB, Oeth P, Braun A, Kammerer S, Ekblom J. Role of ICAM in invasion of human breast cancer cells. Carcinogenesis. 2005;26:943-50.

49. Liang S, Sharma A, Peng HH, Robertson G, Dong C. Targeting mutant (V600E) B-Raf in melanoma interrupts immunoediting of leukocyte functions and melanoma extravasation. Cancer Res. 2007:67:5814-20.

50. Usami Y, Ishida K, Sato S, Kishino M, Kiryu M, Ogawa Y, et al. Intercellular adhesion molecule-1 (ICAM-1) expression correlates with oral cancer progression and induces macrophage / cancer cell adhesion. Int J Cancer. 2013;133:568-78.

51. Tsai ST, Wang PJ, Liou NJ, Lin PS, Chen CH, Chang WC. ICAM1 is a potential cancer stem cell marker of esophageal squamous cell carcinoma. PLoS One. 2015;10:e0142834.

52. Buitrago D, Keutgen XM, Crowley M, Filicori F, Aldailami H, Hoda R, et al. Intercellular adhesion molecule-1 (ICAM-1) is upregulated in aggressive papillary thyroid carcinoma. Ann Surg Oncol. 2012;19:973-80.

53. Xue $F$, Zhang $Y$, Liu F, Jing J, Ma M. Expression of IgSF in salivary adenoid cystic carcinoma and its relationship with invasion and metastasis. J Oral Pathol Med. 2005:34:295-7.

54. Yukinobu M, Akira G, Akihiko K, Hiroshi S, Takatoshi Y, Noriaki T, et al. ICAM1 expression and the soluble ICAM-1 level for evaluating the metastatic potential of gastric cancer. Int J Cancer. 2002;100:486-90. 
55. Grotheyl A, Heistermann P, Philippou S, Voigtmann R. Serum levels of soluble intercellular adhesion molecule- I (ICAMml, CD54) in patients with non-small-cell lung cancer: correlation with histological expression of ICAM-I and tumour stage. Br J Cancer. 1998;77:801-7.

56. Hou C, Lin F, Tong K, Hou S, Liu J. Transforming growth factor alpha promotes osteosarcoma metastasis by ICAM-1 and PI3K / Akt signaling pathway. Biochem Pharmacol. 2014;89:453-63.

57. Yu HS, Lin TH, Tang CH. Involvement of intercellular adhesion molecule-1 up-regulation in bradykinin promotes cell motility in human prostate cancers. Int J Mol Sci. 2013;14:13329-45.

58. Al-husein B, Goc A, Somanath PR. Suppression of interactions between prostate tumor cell-surface integrin and endothelial ICAM-1 by simvastatin inhibits micrometastasis. J Cell Physiol. 2013;228:2139-48.

59. Mccabe NP, Vasanji A, Brainard J, Byzova TV. Prostate cancer specific integrin alphavbeta3 modulates bone metastatic growth and tissue remodeling. Oncogene. 2007;26:6238-43.

60. Wang Y, Xu B, Hu W, Chen L, Wu C, Lu B, et al. High expression of CD11C indicates favorable prognosis in patients with gastric cancer. World J Gastroenterol. 2015;21:9403-12.

61. Garofalo A, Chirivi RGS, Foglieni C, Pigott R, Mortarini R, Martin-Padura I, et al. Involvement of the very late antigen 4 integrin on melanoma in interleukin 1-augmented experimental metastases. Cancer Res. 1995;55:4149.

62. Okahara H, Yagita H, Miyake K, Okumura K. Involvement of very late activation antigen 4 (VLA-4) and vascular cell adhesion molecule 1 (VCAM1) in tumor necrosis factor alpha enhancement of experimental metastasis. Cancer Res. 1994;54:3233-6.

63. Seguin L, Desgrosellier JS, Weis SM, Cheresh DA. Integrins and cancer regulators of cancer stemness, metastasis, and drug resistance. Trends Cell Biol. 2015;25:234-40.

64. Soto MS, Serres S, Anthony DC, Sibson NR. Functional role of endothelial adhesion molecules in the early stages of brain metastasis. Neuro-Oncology. 2014;16:540-51 A.

65. Taichman DB, Cybulsky MI, Djaffar I, Longenecker BM, Teixidó J, Rice GE, et al. Tumor cell surface alpha 4 beta 1 integrin mediates adhesion to vascular endothelium: demonstration of an interaction with the $\mathrm{N}$-terminal domains of INCAM-110/NCAM-1. Cell Regul. 1991;2:347-55.

66. Schlesinger M, Bendas $G$. Contribution of very late antigen-4 ( VLA-4) integrin to cancer progression and metastasis. Cancer Metastasis Rev. 2015; 4:575-91.

67. Juneja HS, Schmalsteig FC, Lee S, Chen J. Vascular cell adhesion molecule-1 and VLA-4 are obligatory adhesion proteins in the heterotypic adherence between human leukemia/lymphoma cells and marrow stromal cells. Exp Hematol. 1993;21:444-50.

68. Sanz-rodríguez F, Teixidó J. VLA-4-dependent myeloma cell adhesion. Leuk Lymphoma. 2001;41:239-45.

69. Shalapour S, Hof J, Kirschner-Schwabe R, Bastian L, Eckert C, Prada J, et al. High VLA-4 expression is associated with adverse outcome and distinct gene expression changes in childhood B-cell precursor acute lymphoblastic leukemia at first relapse. Haematologica. 2011;96:1627-35.

70. Song K, Zhu F, Zhang H, Shang Z. Tumor necrosis factor-a enhanced fusions between oral squamous cell carcinoma cells and endothelial cells via VCAM-1NLA-4 pathway. Exp Cell Res. 2012:318:1707-15.

71. Lessan K, Aguiar DJ, Oegema T, Siebenson L, Skubitz APN. CD44 and $\beta 1$ integrin mediate ovarian carcinoma cell adhesion to peritoneal mesothelial cells. Am J Pathol. 1999;154:1525-37.

72. Bell DA, Longacre TA, Prat J, Kohn EC, Soslow RA, Ellenson LH, et al. Serous borderline (low malignant potential, atypical proliferative) ovarian tumors: workshop perspectives. Hum Pathol. 2003;35:934-48.

73. Scalici JM, Harrer C, Allen A, Jazaeri A, Atkins KA, McLachlan KR, et al. Inhibition of a $4 \beta 1$ integrin increases ovarian cancer response to carboplatin. Gynecol Oncol. 2014;132:455-61.

74. Garmy-susini B, Avraamides CJ, Schmid MC, Foubert P, Ellies LG, Barnes L, et al. Integrin a $4 \beta 1$ signaling is required for lymphangiogenesis and tumor metastasis. Cancer Res. 2010;70:3042-52.

75. Eke I, Deuse $Y$, Hehlgans S, Gurtner K, Krause M, Baumann M, et al. $\beta 1$ integrin / FAK / cortactin signaling is essential for human head and neck cancer resistance to radiotherapy. J Clin Invest. 2012;122:1529-40.

76. Huang C, Park CC, Hilsenbeck SG, Ward R, Rimawi MF, Wang Y, et al. $\beta 1$ integrin mediates an alternative survival pathway in breast cancer cells resistant to lapatinib. Breast Cancer Res. 2011;13:R84. https://doi.org/10.1186/bcr2936.
77. Kanda R, Kawahara A, Watari K, Murakami Y, Sonoda K, Maeda M, et al. Erlotinib resistance in lung cancer cells mediated by integrin $\beta 1 / \mathrm{Src} / \mathrm{Akt}-$ driven bypass signaling. Cancer Res. 2013;73:6243-53.

78. Altevogt P, Doberstein K, Fogel M. L1CAM in human cancer. Int J Cancer. 2016;138:1565-76

79. Burgett ME, Lathia JD, Roth P, Nowacki AS, Galileo DS, Pugacheva E, et al. Direct contact with perivascular tumor cells enhances integrin av $\beta 3$ signaling and migration of endothelial cells. Oncotarget. 2016;7:43852-67.

80. Montgomery AM, Becker JC, Siu CH, Lemmon VP, Cheresh DA, Pancook JD, et al. Human neural cell adhesion molecule L1 and rat homologue NILE are ligands for integrin alpha v beta 3. J Cell Biol. 1996;132:475-85.

81. Rao RM, Yang L, Garcia-Cardena G, Luscinskas FW. Endothelial-dependent mechanisms of leukocyte recruitment to the vascular wall. Circ Res. 2007; 101:234-47.

82. Ruppert M, Aigner S, Hubbe M, Yagita H, Altevogt P. The L1 adhesion molecule is a cellular ligand for VLA-5. J Cell Biol. 1995;131:1881-91.

83. Lindner J, Rathjen FG, Schachner M. L1 mono- and polyclonal antibodies modify cell migration in early postnatal mouse cerebellum. Nature. 1983; 305:427-30.

84. Rathjen FG, Schachner M. Immunocytological and biochemical characterization of a new neuronal cell surface component (L1 antigen) which is involved in cell adhesion. EMBO J. 1984;3:1-10.

85. Sebens Müerköster S, Werbing V, Sipos B, Debus MA, Witt M, Großmann M, et al. Drug-induced expression of the cellular adhesion molecule L1CAM confers anti-apoptotic protection and chemoresistance in pancreatic ductal adenocarcinoma cells. Oncogene. 2007;26:2759-68.

86. Schäfer MKE, Altevogt P. L1CAM malfunction in the nervous system and human carcinomas. Cell Mol Life Sci. 2010;67:2425-37.

87. Kiefel H, Bondong S, Hazin J, Ridinger J, Schirmer U, Riedle S, et al. L1CAM: a major driver for tumor cell invasion and motility. Cell Adhes Migr. 2012;6: 374-84.

88. Gavert N, Conacci-Sorrell M, Gast D, Schneider A, Altevogt P, Brabletz T, et al. $L 1$, a novel target of $\beta$-catenin signaling, transforms cells and is expressed at the invasive front of colon cancers. J Cell Biol. 2005;168:633-42.

89. Gavert N, Ben-Shmuel A, Raveh S, Ben-Ze'ev A. L1-CAM in cancerous tissues. Expert Opin Biol Ther. 2008:8:1749-57.

90. Allory Y, Matsuoka Y, Bazille C, Christensen El, Ronco P, Debiec H. The L1 cell adhesion molecule is induced in renal cancer cells and correlates with metastasis in clear cell carcinomas. Clin Cancer Res. 2005;11:1190-7.

91. Fogel M, Gutwein P, Mechtersheimer S, Riedle S, Stoeck A, Smirnov A, et al. $\mathrm{L} 1$ expression as a predictor of progression and survival in patients with uterine and ovarian carcinomas. Lancet. 2003;362:869-75.

92. Beer S, Oleszewski M, Gutwein P, Geiger C, Altevogt P. Metalloproteinasemediated release of the ectodomain of $\mathrm{L} 1$ adhesion molecule. J Cell Sci. 1999:2675:2667-75

93. Craig SEL, Brady-Kalnay SM. Cancer cells cut Homophilic cell adhesion molecules and run. Cancer Res. 2011:71:303-9.

94. Mechtersheimer S, Gutwein P, Agmon-Levin N, Stoeck A, Oleszewski M, Riedle $\mathrm{S}$, et al. Ectodomain shedding of $\mathrm{L} 1$ adhesion molecule promotes cell migration by autocrine binding to integrins. J Cell Biol. 2001;155:661-73.

95. Stoeck A, Gast D, Sanderson MP, Issa Y, Gutwein P, Altevogt P. L1-CAM in a membrane-bound or soluble form augments protection from apoptosis in ovarian carcinoma cells. Gynecol Oncol. 2007:104:461-9.

96. Friedli A, Fischer E, Novak-Hofer I, Cohrs S, Ballmer-Hofer K, Schubiger PA, et al. The soluble form of the cancer-associated L1 cell adhesion molecule is a pro-angiogenic factor. Int J Biochem Cell Biol. 2009;41:1572-80.

97. Kaifi JT, Reichelt U, Quaas A, Schurr PG, Wachowiak R, Yekebas EF, et al. L1 is associated with micrometastatic spread and poor outcome in colorectal cancer. Mod Pathol. 2007;20:1183-90.

98. Boo Y, Park J, Kim J, Chae Y, Min B, Um J, et al. L1 expression as a marker for poor prognosis, tumor progression, and short survival in patients with colorectal cancer. Ann Surg Oncol. 2007;14:1703-11.

99. Gavert N, Sheffer M, Raveh S, Spaderna S, Shtutman M, Brabletz T, et al. Expression of L1-CAM and ADAM10 in human colon cancer cells induces metastasis. Cancer Res. 2007;67:7703-12.

100. Zecchini S, Bianchi M, Colombo N, Fasani R, Goisis G, Casadio C, et al. The differential role of $L 1$ in ovarian carcinoma and normal ovarian surface epithelium. Cancer Res. 2008:68:1110-8.

101. Meier F, Busch S, Gast D, Göppert A, Altevogt P, Maczey E, et al. The adhesion molecule L1 (CD171) promotes melanoma progression. Int J Cancer. 2006;119:549-55. 
102. Thies A, Schachner M, Moll I, Berger J, Schulze H-J, Brunner G, et al. Overexpression of the cell adhesion molecule L1 is associated with metastasis in cutaneous malignant melanoma. Eur J Cancer. 2002;38:1708-16.

103. Kaifi JT, Heidtmann S, Schurr PG, Reichelt U, Mann O, Yekebas EF, et al. Absence of $L 1$ in pancreatic masses distinguishes adenocarcinomas from poorly differentiated neuroendocrine carcinomas. Anticancer Res. 2006;26: 1167-70.

104. Horak CE, Lee JH, Elkahloun AG, Boissan M, Dumont S, Maga TK, et al. $\mathrm{Nm} 23-\mathrm{H} 1$ suppresses tumor cell motility by down-regulating the lysophosphatidic acid receptor EDG2. Cancer Res. 2007;67:7238-46.

105. Cooper $\mathrm{CR}$, Chay $\mathrm{CH}$, Pienta $\mathrm{KJ}$. The role of $\mathrm{a}(\mathrm{v}) \beta(3)$ in prostate cancer progression. Neoplasia. 2002;4:191-4.

106. Maric G, Annis MG, Dong Z, Rose AAN, Ng S, Perkins D, et al. GPNMB cooperates with neuropilin-1 to promote mammary tumor growth and engages integrin a5 $\beta 1$ for efficient breast cancer metastasis. Oncogene. 2015:34:5494-504.

107. Voura EB, Ramjeesingh RA, Montgomery AMP, Siu CH. Involvement of integrin $\mathrm{a}(\mathrm{v}) \beta(3)$ and cell adhesion molecule $\mathrm{L} 1$ in transendothelial migration of melanoma cells. Mol Biol Cell. 2001;12:2699-710.

108. Liu Z, Wang F, Chen X. Integrin a(v) B(3)-targeted cancer therapy. Drug Dev Res. 2008;69:329-39.

109. Heß K, Böger C, Behrens H, Röcken C. Annals of diagnostic pathology correlation between the expression of integrins in prostate cancer and clinical outcome in 1284 patients. Ann Diagn Pathol. 2014;18:343-50.

110. Goodman SL, Grote HJ, Wilm C. Matched rabbit monoclonal antibodies against av-series integrins reveal a novel avß3-LIBS epitope, and permit routine staining of archival paraffin samples of human tumors. Biol Open. 2012;1:329-40

111. Hsu MY, Shih DT, Meier FE, Van Belle P, Hsu JY, Elder DE, et al. Adenoviral gene transfer of $\beta 3$ integrin subunit induces conversion from radial to vertical growth phase in primary human melanoma. Am J Pathol. 1998;153:1435-42.

112. Huang R, Rofstad EK. Integrins as therapeutic targets in the organ-specific metastasis of human malignant melanoma. J Exp Clin Cancer Res. 2018;37: 92. https://doi.org/10.1186/s13046-018-0763-x.

113. Van Belle PA, Elenitsas R, Satyamoorthy K, Wolfe JT, Guerry D, Schuchter L, et al. Progression-related expression of $\beta 3$ integrin in melanomas and nevi. Hum Pathol. 1999;30:562-7.

114. Nikkola J, Vihinen P, Vlaykova T, Hahka-Kemppinen M, Heino J, Pyrhönen S. Integrin chains $\beta 1$ and av as prognostic factors in human metastatic melanoma. Melanoma Res. 2004;14:29-37.

115. Klemke M, Weschenfelder T, Konstandin MH, Samstag Y. High affinity interaction of integrin a $4 \beta 1$ (VLA-4) and vascular cell adhesion molecule 1 (VCAM-1) enhances migration of human melanoma cells across activated endothelial cell layers. J Cell Physiol. 2007;212:368-74.

116. Whilding LM, Parente-Pereira AC, Zabinski T, Davies DM, Petrovic RMG, Kao YV, et al. Targeting of aberrant av $\beta 6$ integrin expression in solid tumors using chimeric antigen receptor-engineered T cells. Mol Ther. 2017;25:259-73.

117. Millard M, Odde S, Neamati N. Integrin targeted therapeutics. Theranostics. 2011;1:154-88

118. Raab-westphal S, Marshall JF, Goodman SL. Integrins as Therapeutic Targets: Successes and Cancers. Cancers (Basel). 2017;9(9):110. Published 2017 Aug 23. https://doi.org/10.3390/cancers9090110.

119. Goodman SL, Picard M. Integrins as therapeutic targets. Trends Pharmacol Sci. 2012;33:405-12.

120. Trikha M, Zhou Z, Nemeth JA, Chen Q, Sharp C, Emmell E, et al. CNTO 95, a fully human monoclonal antibody that inhibits av integrins, has antitumor and antiangiogenic activity in vivo. Int J Cancer. 2004;110:326-35.

121. O'Day S, Pavlick A, Loquai C, Lawson D, Gutzmer R, Richards J, et al. A randomised, phase II study of intetumumab, an anti- $a(v)$-integrin $m A b$, alone and with dacarbazine in stage IV melanoma. Br J Cancer. 2011;105: 346-52.

122. Pickarski M, Gleason A, Bednar B, Duong LT. Orally active avß3 integrin inhibitor MK-0429 reduces melanoma metastasis. Oncol Rep. 2015;33:2737-45.

123. Rosenthal MA, Davidson P, Rolland F, Campone M, Xue L, Han TH, et al. Evaluation of the safety, pharmacokinetics and treatment effects of an av $\beta 3$ integrin inhibitor on bone turnover and disease activity in men with hormone-refractory prostate cancer and bone metastases. Asia Pac J Clin Oncol. 2010;6:42-8.

124. Juan-Rivera MC, Martínez-Ferrer M. Integrin inhibitors in prostate cancer. Cancers (Basel). 2018;10(2):44. Published 2018 Feb 6. https://doi.org/10.3390/ cancers10020044.
125. Hersey P, Sosman J, O'Day S, Richards J, Bedikian A, Gonzalez R, et al. A randomized phase 2 study of etaracizumab, a monoclonal antibody against integrin av $\beta 3, \pm$ dacarbazine in patients with stage IV metastatic melanoma. Cancer. 2010;116:1526-34.

126. Hariharan S, Gustafson D, Holden S, McConkey D, Davis D, Morrow M, et al. Assessment of the biological and pharmacological effects of the av $\beta 3$ and av $\beta 5$ integrin receptor antagonist, cilengitide (EMD 121974), in patients with advanced solid tumors. Ann Oncol. 2007;18:1400-7.

127. Kim KB, Prieto V, Joseph RW, Diwan AH, Gallick GE, Papadopoulos NE, et al. A randomized phase II study of cilengitide ( EMD 121974) in patients with metastatic melanoma. Melanoma Res. 2000;22:294-301.

128. Gvozdenovic A, Boro A, Meier D, Bode-Lesniewska B, Born W, Muff R, et al. Targeting av $\beta 3$ and av $\beta 5$ integrins inhibits pulmonary metastasis in an intratibial xenograft osteosarcoma mouse model. Oncotarget. 2016;7:55141-54.

129. Kurozumi K, Ichikawa T, Onishi M, Fujii K, Date I. Cilengitide treatment for malignant glioma: current status and future direction. Neurol Med Chir (Tokyo). 2012:52:539-47.

130. Mason WP. End of the road: confounding results of the CORE trial terminate the ardous journey of cilengitide for glioblastoma. Neuro-Oncology. 2015; 17:634-5.

131. Jiang Y, Dai J, Yao Z, Shelley G, Keller ET. Abituzumab targeting of a V-class Integrins inhibits prostate cancer progression. Mol Cancer Res. 2017;15:875-84.

132. Wirth M, Heidenreich A, Gschwend E, Gil T, Zastrow S, Mordenti G, et al. A multicenter phase 1 study of EMD 525797 (DI17E6), a novel humanized monoclonal antibody targeting av integrins, in progressive castrationresistant prostate cancer with bone metastases after chemotherapy. Eur Urol. 2014;65:897-904.

133. Élez E, Kocáková I, Höhler T, Martens UM, Bokemeyer C, Van Cutsem E, et al. Abituzumab combined with cetuximab plus irinotecan versus cetuximab plus irinotecan alone for patients with KRAS wild-type metastatic colorectal cancer : the randomised phase I / II POSEIDON trial. Ann Oncol. 2015;26:132-40.

134. Lin T, Tan T, Tsai T, Chen C, Hsieh T. D-pinitol inhibits prostate cancer metastasis through inhibition of aVB3 integrin by modulating FAK, C-SrC and NF-KB pathways. Int J Mol Sci. 2013;14:9790-802.

135. van der Horst G, van den Hoogen C, Buijs JT, Cheung H, Bloys H, Pelger RCM, et al. Targeting of a(v)-Integrins in stem/progenitor cells and supportive microenvironment impairs bone metastasis in human prostate cancer. Neoplasia. 2011;13:516-25.

136. Cirkel GA, Kerklaan BM, Vanhoutte F, Van Der Aa A, Lorenzon G, Namour F, et al. A dose escalating phase I study of GLPG0187, a broad spectrum integrin receptor antagonist, in adult patients with progressive high-grade glioma and other advanced solid malignancies. Investig New Drugs. 2016; 34:184-92.

137. Stachurska A, Elbanowski J, Kowalczyńska HM. Role of a5ß1 and avß3 integrins in relation to adhesion and spreading dynamics of prostate cancer cells interacting with fibronectin under in vitro conditions. Cell Biol Int. 2013;36:883-92.

138. Reynolds LE, Wyder L, Lively JC, Taverna D, Robinson SD, Huang X, et al. Enhanced pathological angiogenesis in mice lacking $\beta 3$ integrin or $\beta 3$ and $\beta 5$ integrins. Nat Med. 2002;8:27-34.

139. Almokadem S, Belani CP. Volociximab in cancer. Expert Opin Biol Ther. 2012; 12:251-7.

140. Bell-mcguinn KM, Matthews CM, Ho SN, Barve M, Gilbert L, Penson RT, et al A phase II, single-arm study of the anti-a5 $\beta 1$ integrin antibody volociximab as monotherapy in patients with platinum-resistant advanced epithelial ovarian or primary peritoneal cancer. Gynecol Oncol. 2011;121:273-9.

141. Mateo J, Berlin J, de Bono JS, Cohen RB, Keedy V, Mugundu G, et al. A firstin-human study of the anti-a5 $\beta 1$ integrin monoclonal antibody PF04605412 administered intravenously to patients with advanced solid tumors. Cancer Chemother Pharmacol. 2014;74:1039-46.

142. Stoeltzing O, Liu W, Reinmuth N, Fan F, Parry GC, Parikh AA, et al. Inhibition of integrin a5 31 function with a small peptide (ATN-161) plus continuous 5FU infusion reduces colorectal liver metastases and improves survival in mice. Int J Cancer. 2003;104:496-503.

143. Cianfrocca ME, Kimmel KA, Gallo J, Cardoso T, Brown MM, Hudes G, et al. Phase 1 trial of the antiangiogenic peptide ATN-161 in patients with solid tumours. Br J Cancer. 2006;161:1621-6.

144. Zhang N, Xia Y, Zou Y, Yang W, Zhang J, Zhong Z, et al. ATN-161 peptide functionalized reversibly cross-linked polymersomes mediate targeted doxorubicin delivery into melanoma-bearing C57BL/6 mice. Mol Pharm. 2017;14:2538-47. 
145. Ley K, Rivera-Nieves J, Sandborn WJ, Shattil S. Integrin-based therapeutics: biological basis, clinical use and new drugs. Nat Rev Drug Discov. 2016;15:173-83.

146. Sheldrake HM, Patterson LH. Strategies to inhibit tumor associated integrin receptors: rationale for dual and multi-antagonists. J Med Chem. 2014;57: 6301-15.

147. Calderwood DA, Tai V, Di G, De Camilli P, Ginsberg MH. Competition for Talin results in trans-dominant inhibition of integrin activation. J Biol Chem. 2004;279:28889-95.

148. Merlino F, Daniele S, La Pietra V, Di Maro S, Saverio F, Leva D, et al. Simultaneous targeting of RGD-integrins and dual murine double minute proteins in glioblastoma multiforme. J Med Chem. 2018:61:4791-809.

149. Khaustova NA, Maltseva DV, Oliveira-Ferrer L, Stürken C, Milde-Langosch K, Makarova JA, et al. Selectin-independent adhesion during ovarian cancer metastasis. Biochimie. 2017;142:197-206.

150. Gebauer F, Wicklein D, Stu K, Nehmann N, Schmidt A, Salamon J, et al. Selectin binding is essential for peritoneal carcinomatosis in a xenograft model of human pancreatic adenocarcinoma in pfp- -/rag2- - mice. Gut. 2013;62:741-50

151. Bökel C, Brown NH. Integrins in development: moving on, responding to, and sticking to the extracellular matrix. Dev Cell. 2002;3:311-21.

152. Cox D, Brennan M, Moran N. Integrins as therapeutic targets: lessons and opportunities. Nat Rev Drug Discov. 2010;9:804-20.

153. Fässler R, Meyer M. Consequences of lack of $B 1$ integrin gene expression in mice. Genes Dev. 1995:9:1896-908.

154. Axelsson R, Bach-Gansmo T, Castell-Conesa J, McParland BJ. An open-label, multicenter, phase 2a study to assess the feasibility of imaging metastases in late-stage cancer patients with the avß3-selective angiogenesis imaging agent 99mtc-nc100692. Acta Radiol. 2010;51:40-6.

155. Kenny LM, Coombes RC, Oulie I, Contractor KB, Miller M, Spinks TJ, et al. Phase I trial of the positron-emitting 18F-AH111585 in breast cancer patients. J Nucl Med. 2018;49(6):879-87.

156. Frenette BPS, Denis CV, Weiss L, Jurk K, Subbarao S, Kehrel B, et al. P-selectin glycoprotein ligand 1 (PSGL-1) is expressed on platelets and can mediate platelet- endothelial interactions in vivo. J Exp Med. 2000;191:1413-22.

157. Humphries MJ, Symonds EJH, Mould AP. Mapping functional residues onto integrin crystal structures. Curr Opin Struct Biol. 2003;13:236-43.

Ready to submit your research? Choose BMC and benefit from:

- fast, convenient online submission

- thorough peer review by experienced researchers in your field

- rapid publication on acceptance

- support for research data, including large and complex data types

- gold Open Access which fosters wider collaboration and increased citations

- maximum visibility for your research: over $100 \mathrm{M}$ website views per year

At $\mathrm{BMC}$, research is always in progress.

Learn more biomedcentral.com/submissions 